OPEN ACCESS

Edited by:

Hailiang Tang,

Department of Neurosurgery,

Huashan Hospital Affiliated to Fudan

University, China

Reviewed by:

$X i$ Yang,

Fudan University, China Tongming Zhu,

Huashan Hospital, Fudan

University, China

*Correspondence:

Gui-Jun Jia

jiaguijun2013@163.com

Jun-Ting Zhang

zhangjunting2003@aliyun.com

Bai-Nan Xu

xubainan_301@163.com

Specialty section:

This article was submitted to

Neuro-Oncology and Neurosurgical

Oncology,

a section of the journa

Frontiers in Oncology

Received: 27 February 2020

Accepted: 08 July 2020

Published: 25 August 2020

Citation:

Zhang $Q$, Song $L-R$, Huo X-L,

Wang $L$, Zhang G-B, Hao $S-Y$,

Jia $H$-W, Kong C-L, Jia W, Wu Z,

Xu B-N, Jia G-J and Zhang J-T (2020)

MicroRNA-221/222 Inhibits the

Radiation-Induced Invasiveness and

Promotes the Radiosensitivity of

Malignant Meningioma Cells.

Front. Oncol. 10:1441.

doi: 10.3389/fonc.2020.01441

\section{MicroRNA-221/222 Inhibits the Radiation-Induced Invasiveness and Promotes the Radiosensitivity of Malignant Meningioma Cells}

Qing Zhang ${ }^{1}$, Lai-Rong Song 2,3,4,5, Xu-Lei Huo 2,3,4,5, Liang Wang 2,3,4,5, Guo-Bin Zhang ${ }^{2,3,4,5}$, Shu-Yu Hao ${ }^{2,3,4,5}$, Hai-Wei Jia ${ }^{6}$, Chui-Lin Kong ${ }^{6}$, Wang Jia ${ }^{2,3,4,5}$, Zhen Wu ${ }^{2,3,4,5}$, Bai-Nan Xu ${ }^{1 *}$, Gui-Jun Jia ${ }^{2,3,4,5 *}$ and Jun-Ting Zhang ${ }^{2,3,4,5 *}$

${ }^{1}$ Department of Neurosurgery, Chinese People's Liberation Army General Hospital, Beijing, China, ${ }^{2}$ Department of Neurosurgery, Beijing Tian Tan Hospital, Capital Medical University, Beijing, China, ${ }^{3}$ China National Clinical Research Center for Neurological Diseases, Beijing, China, ${ }^{4}$ Center of Brain Tumor, Beijing Institute for Brain Disorders, Beijing, China, ${ }^{5}$ Beijing Key Laboratory of Brain Tumor, Beijing, China, ${ }^{6}$ Department of Radiotherapy, Beijing Fengtai You Anmen Hospital, Beijing, China

The controversy of adjuvant radiotherapy of meningiomas is at least partially due to the insufficient understanding on meningioma cells' response to irradiation and the shortage of radiosensitivity-promotion methods. MicroRNA-221 and microRNA-222 were identified as critical regulators of radiosensitivity in several other tumors. However, their effect in meningiomas has yet to be confirmed. Therefore, the malignant meningioma IOMM-Lee cells were adopted, transfected with microRNA-221/222 mimics or inhibitors, and irradiated with different dosages. The effects of radiation and microRNA-221/222 were then assessed in vitro and in vivo. Radiation dose increases and microRNA-221/222 downregulation synergistically inhibited cell proliferation and colony formation, prevented xenograft tumor progression, and promoted apoptosis, but antagonistically regulated cell invasiveness. Pairwise comparisons revealed that only high-dose radiations (6 and 8 Gy) can significantly promote cell invasiveness in comparison with unirradiated counterparts. Further comparisons exhibited that downregulating the microRNA-221/222 expression can reverse this radiation-induced cell invasiveness to a level of untransfected and unirradiated cells only if cells were irradiated with no more than 6 Gy. In addition, this approach can promote IOMM-Lee's radiosensitivity. Meanwhile, we also detected that the dose rate of irradiation affects cell cycle distribution and cell apoptosis of IOMM-Lee. A high dose rate irradiation induces G0/G1 cell cycle arrest and apoptosis-promoting effect. Therefore, for malignant meningiomas, high-dose irradiation can facilitate cell invasiveness significantly. Downregulating the microRNA-221/222 level can reverse the radiation-induced cell invasiveness while enhancing the apoptosis-promoting and proliferation-inhibiting effects of radiation and promoting cell radiosensitivity.

Keywords: invasiveness, radiosensitivity, microRNA-221/222, IOMM-Lee, dose rate, epithelial-mesenchymal transition-inducing transcription factors 


\section{INTRODUCTION}

Meningiomas, one of the most common primary intracranial neoplasms, are classified into WHO grades I-III on the basis of local invasiveness and cellular features of atypia (1). Surgical resection is the primary treatment. As an important component of the therapeutic management of meningiomas, external beam radiotherapy aims to control tumor growth of surgically inaccessible tumors and in residual or recurrent lesions after surgery, ideally to achieve safe dose escalation and effective toxicity avoidance (e.g., necrosis of brain parenchyma, neurocognitive dysfunction, hypopituitarism, radiation-induced tumors, and malignant transformation) (2). However, radiotherapy has always been controversial, for instance, its necessity for WHO grade II lesions with different extents of resection (2-8), the optimal dosage (9-13), timing $(7,12,14)$, etc. Thus, elucidation of how radiation exposure affects meningioma cells and exploration of the possible regulatory mechanism of radiosensitivity are indispensable for improved treatment.

MicroRNAs (miRs) are a family of endogenously synthesized small non-coding RNAs that regulate gene expression by influencing the protein translational machinery and/or inducing degeneration of target messenger RNAs (mRNAs) $(15,16)$. Genome-wide studies have demonstrated that miRNA genes are frequently located in cancer-associated genomic regions, indicating the potential roles of miRNAs in tumorigenesis (17). Previous studies on meningioma have suggested that several miRNAs participate in the regulation of cell proliferation (18$21)$, apoptosis $(19,22)$, invasiveness $(19,23)$, migration $(19,24)$, tumor recurrence (25-27), and histopathological progression $(18,19,25,27-29)$. However, no miRNAs have been verified to affect the radiosensitivity of meningiomas. MiR-221 and miR222 , both located on the $\mathrm{X}$ chromosome with the same seed sequences, were confirmed to be involved in regulating the radiosensitivity of glioblastoma (30), gastric carcinoma (31), colorectal carcinoma $(32,33)$, and nasopharyngeal carcinoma (34). However, relevant research on the radiosensitivity of meningioma is lacking. In the present study, we aimed to reveal the effect of radiation on meningioma cells and the role of $m i R-221 / 222$ in regulating meningioma radiosensitivity.

\section{MATERIALS AND METHODS}

\section{Cells and Cell Culture}

The meningioma cell line IOMM-Lee (ATCC Cat. No. CRL3370, RRID: CVCL_5779) was kindly provided by Professor JinHong Mei (Nanchang University, China) and was authenticated completely match with IOMM-Lee in the American Type Culture Collection (ATCC) short tandem repeat (STR) database without any cross-contamination of other human cell lines before and after this research. Cells were grown in Dulbecco's modified

Abbreviations: DMEM, Dulbecco's modified Eagle's medium; FACS, fluorescenceactivated cell-sorting; miR, microRNA; SER, sensitization enhancement ratio; SF, survival fraction.
Eagle's medium (DMEM; HyClone, USA) supplemented with $10 \%$ fetal bovine serum at $37^{\circ} \mathrm{C}$ in a $5 \% \mathrm{CO}_{2}$ atmosphere.

\section{Cell Transfection}

The miR-221/222 mimics and inhibitors were chemically synthesized by RiboBio Co., Ltd. (Guangzhou, China) and were transfected into IOMM-Lee cells with riboFECT ${ }^{\mathrm{TM}} \mathrm{CP}$ reagent according to the manufacturer's instructions. Scrambled oligonucleotides (GenePharma Co., Ltd., Shanghai, China) were also transfected as a negative control. The expression levels of $m i R-221$ and $m i R-222$ in transfected IOMM-Lee cells were identified by quantitative real-time PCR.

\section{Radiation Exposure}

Irradiation was performed at room temperature in a linear accelerator (Varian600, Varian, USA) at a dose rate of $3.2 \mathrm{~Gy} / \mathrm{min}$ $(31,33)$. Cells were plated into six-well plates and exposed to the specified dose $(0,2,4,6$, and $8 \mathrm{~Gy})$ of X-rays.

\section{Clonogenic Assay}

A clonogenic assay was applied to determine the radiosensitivity of IOMM-Lee cells. A predetermined number of viable cells (1,000 cells for 0,2 , and $4 \mathrm{~Gy} ; 2,000$ cells for 6 and $8 \mathrm{~Gy})$ were seeded in six-well culture plates and incubated at $37^{\circ} \mathrm{C}$ for $24 \mathrm{~h}$. Next, the cells were irradiated with different doses and then incubated for 7 days to allow colony growth. Then, colonies were stained with crystal violet, and those containing 50 or more cells were counted. The plating efficiency was calculated by dividing the average number of counted colonies by the number of seeded cells. Survival fractions (SFs) were calculated by normalization to the plating efficiency of the respective unirradiated controls (32). After estimation of the $\mathrm{SF}$ at different radiation doses, the survival curve (log of SF vs. the radiation dose) was plotted, and the $D_{0}$ value for each group was calculated using the following equation: $\mathrm{SF}=1-\left(1-\mathrm{e}^{\mathrm{D} / \mathrm{D} 0}\right)^{\mathrm{n}}(32)$. The $\mathrm{D}_{0}$ value, which represents the radiation dose required to reduce the SF from 100 to $37 \%$, is considered a measure of the intrinsic radiosensitivity of cells (33). The sensitization enhancement ratio for each treated group was determined by the ratio of the $\mathrm{D}_{0}$ of the control group to that of the treated group (33).

\section{Cell Proliferation Assay}

Cells were seeded into 96-well plates at a density of $2 \times 10^{3}$ cells per well and cultured for $12 \mathrm{~h}$. Cell proliferation was assessed using a Cell Counting Kit-8 assay (Fluorescence, Beijing, China) according to the manufacturer's instructions. Absorbance was measured at a wavelength of $450 \mathrm{~nm}$ on a Model 550 microplate reader (Bio-Rad Laboratories, Hercules, CA, USA).

\section{Cell Cycle and Apoptosis Analyses by Flow Cytometry}

The effects of miR-221/222 and irradiation on the cell cycle and apoptosis in IOMM-Lee cells were examined by flow cytometry. Pretreated IOMM-Lee cells in the log phase of growth were stained with Annexin V/fluorescein isothiocyanate (FITC) and propidium iodide (Beyotime, China). Cell cycle and apoptotic rate were examined with a fluorescence-activated cell-sorting 
(FACS) flow cytometer (BeamCyte, China), and the data were analyzed using CellQuest Software. The percentages of cells in G0/G1 phase and the apoptotic rate were measured by calculating the ratio of the number of corresponding cells and that of total cells. For each sample, 10,000 cells were measured.

\section{Invasion Assay}

The invasive potential of the pretreated cells was evaluated by measuring the number of cells that invaded Matrigel-coated Transwell chambers. Prior to the experiment, Transwell inserts with $8-\mu \mathrm{m}$ pores were coated with Matrigel and reconstituted with fresh medium for $2 \mathrm{~h}$. Cells $\left(1 \times 10^{5} / \mathrm{ml}\right)$ were seeded into the upper chambers in $200 \mu \mathrm{l}$ serum-free DMEM, while DMEM supplemented with $10 \%$ fetal bovine serum $(700 \mu \mathrm{l})$ was placed in the lower chamber. After incubation for $48 \mathrm{~h}$, cells that degraded the Matrigel and invaded the lower surface of the Matrigelcoated membrane were fixed with $70 \%$ ethanol, stained with hematoxylin, and counted in five random fields at a magnification $\times 200$ under an optical microscope.

\section{Dual Luciferase Reporter Assay}

The $3^{\prime}$-untranslated region (UTR) of phosphatase and tensin homolog (PTEN), which contains the predicted binding sites of miR-221/222, were cloned into the XhoI site of the psi-check2 reporter vector (Biomed, Beijing, China). For the luciferase reporter assays, IOMM-Lee cells were cultured in 24-well plates with three replicates, incubated for $24 \mathrm{~h}$, and transfected with $500 \mathrm{ng}$ of psi-check2-PTEN or psi-check2-control plasmids with/without $100 \mathrm{nM}$ miR-221 mimics or miR-222 mimics using Lipofectamine 3000. Luciferase activity was measured $48 \mathrm{~h}$ after transfection using dual-luciferase reporter assay system (Promega, WI, USA) according to the manufacturer's procedures. Data were normalized by Firefly/Renilla luciferase activity.

\section{Western Blot Analysis}

Protein of IOMM-Lee cells from each subgroup was extracted using radioimmunoprecipitation assay (RIPA) buffer (Beyotime, Shanghai, China). Their concentration was determined using a BCA Protein Assay Kit (Beyotime, Shanghai, China). Equal amounts of protein $(5 \mu \mathrm{g})$ were then subjected to $10 \%$ sodium dodecyl sulfate-polyacrylamide gel electrophoresis (SDS-PAGE) followed by transfer of protein to polyvinylidene fluoride (PVDF) membranes (Millipore, Darmstadt, Germany). Membranes were subsequently blocked in Tris-buffered saline containing $0.1 \%$ Tween-20 and 5\% skimmed milk powder and were incubated with primary antibodies against PTEN (1:1,000 dilution) and $\beta$ actin (1:4,000 dilution) (Cell Signaling Technology, MA, USA) overnight at $4{ }^{\circ} \mathrm{C}$. Horseradish peroxidase (HRP)-conjugated secondary antibodies for PTEN (1:2,000 dilution) and $\beta$-actin (1:4,000 dilution) (Cell Signaling Technology, MA, USA) were used afterward. The blots were detected using Pierce ${ }^{\mathrm{TM}}$ ECL Western Blotting Substrate (Thermo Fisher Scientific, Rockford, USA), and the membranes were developed using a ChemiDoc MP imaging system (Bio-Rad, Hercules, CA).

\section{In vivo Studies}

All animal studies were conducted in accordance with an approved institutional animal care and use committee protocol of our hospital (202001014). IOMM-Lee cells $\left(5 \times 10^{6}\right)$ were injected subcutaneously into the flank position of 5-week-old female $\mathrm{BALB} / \mathrm{c}$ nude mice. When the tumors reached $5 \mathrm{~mm}$ in diameter, animals were randomly divided into 4 groups of 16 mice each and were, respectively treated with intratumoral injections of saline, scramble oligonucleotides, miR-221/222-3p agomirs, and $m i R-221 / 222-3 p$ antagomirs (RiboBio, Guangzhou, China) every 4 days for a total of three doses $(3 \mathrm{nmol} / \mathrm{dose})$. Eight animals from each group were radiated with two doses of $4 \mathrm{~Gy}$ during the intervals between injections. The entire mouse body except the tumor area was covered with lead sheets to avoid exposure to radiation during treatments. Vernier caliper was used to measure the length and width of tumors on alternate days, and tumor volumes were calculated as $\pi / 6 \times$ (length $\times$ width $^{2}$ ). Regression in subcutaneous tumor growth was followed, and mice were euthanized when tumor rupture and hemorrhage were observed in unradiated-control group. Immediately after the removal of the tumors, half of each tumor was stored in liquid nitrogen for the subsequent quantification of $m i R-221$ and $m i R$ 222 by using quantitative real-time PCR (qRT-PCR); the other half was fixed in buffered formaldehyde and was sectioned and subjected to the later $\mathrm{H} \& \mathrm{E}$ and immunohistochemical staining for PTEN.

\section{Statistical Analysis}

The abovementioned experiments were performed at least in triplicate, and data are presented as the mean \pm standard deviation. The effects of miR-221/222 expression level and radiation dose on IOMM-Lee cells in vitro and in vivo were tested with two-way analysis of variance. Simple effect and pairwise comparisons with Bonferroni posttest were performed if the interaction between the factors appeared significant; otherwise, main effect and multiple comparisons with Bonferroni posttest were performed. Further comparisons of invasive cell numbers between the inhibitor group and the control/scramble group exposed to different radiation doses were analyzed by independent-sample $t$-tests. Multiple comparisons of xenograft tumor volumes between different treatment groups were analyzed by ANOVA with Bonferroni posttest. All $P$ values are two-sided, and significance was defined using a threshold of 0.05 . Statistical analyses were performed with SPSS version 19.0 (IBM Corp. Armonk, New York, USA).

\section{RESULTS}

\section{Modulation of $m i R-221 / 222$ Expression in IOMM-Lee Cell Line}

IOMM-Lee cells were transfected with $m i R-221 / 222$ mimics or inhibitors. qRT-PCR revealed that no significant difference in $m i R-221$ and $m i R-222$ expression between the control and the scramble group ( $m i R-221: P=0.7640, m i R-222: P=0.0856)$. Compared with that in either the control or the scramble group, the expression of $m i R-221$ and $m i R-222$ increased significantly in the miR-221/222-mimic group ( $m i R-221$ : vs. control, $P<0.0001$; 
vs. scramble, $P<0.0001$; $m i R-222$ : vs. control, $P<0.0001$; vs. scramble, $P<0.0001$ ), while it decreased significantly in the $m i R-221 / 222$-inhibitor group ( $m i R-221$ : vs. control, $P<0.0001$; vs. scramble, $P<0.0001$; $m i R-222$ : vs. control, $P<0.0001$; vs. scramble, $P<0.0001$ ) (Figures 1A,B).

\section{Radiation Dose and Expression Level of miR-221/222 Synergistically Modulate IOMM-Lee Cell Proliferation, Apoptosis, and Cell Cycle Distribution}

With an increase in radiation dose or a decrease in $m i R$ $221 / 222$ expression level, the absorbance and colony number of IOMM-Lee cells decreased gradually, while apoptotic percentage and G0/G1 phase percentage increased; however, their invasive cell number increased as the radiation dose increased and decreased as the $m i R-221 / 222$ expression level decreased (Table 1, Figure 1). Two-way ANOVA revealed significant simple effects of radiation dose and $m i R-221 / 222$ expression level and their significant interactions in the proliferation, colony formation, apoptosis, and invasiveness of IOMM-Lee cells, while it exhibited their significant main effects in the sub-G0/G1 population, yet without significant interactions (Table 2).

Increasing radiation dose and downregulating $m i R-221 / 222$ expression have synergistic effects on inhibiting proliferation and promoting apoptosis of IOMM-Lee cells (Tables 1, 2). Significant decrease in cell absorbance and colony number appears at each step-up of irradiation dose or each fall of the $m i R-221 / 222$ expression (Tables 3, 5 and Figures 1C,I), indicating that the proliferation-inhibiting effect of radiation can be significantly enhanced by downregulating $m i R-221 / 222$ expression.

As to the apoptosis of IOMM-Lee cells, pairwise comparisons of different groups revealed that, by irradiating with the same dosage, the apoptosis rate was significantly increased with downregulation of $m i R-221 / 222$ expression (Table 5 and Figures 1D,E). Meanwhile, (1) the radiation dose that initially significantly promoted cell apoptosis was much higher in the $m i R-221 / 222$-mimic group (6Gy) than in the other groups ( $2 \mathrm{~Gy}$ ) compared to their respective unirradiated cells; (2) within irradiated IOMM-Lee cells, the significant increase in apoptotic rate caused by each step-up of irradiation dose, which can be seen in cells with regular or decreased $m i R-221 / 222$ expression, was not observed as the expression of $m i R-221 / 222$ promoted; (3) in the comparisons between two irradiated subgroups with an incremental gradient of 4 or $6 \mathrm{~Gy}$, the apoptosis rate increased significantly in the control, scramble, and $m i R-221 / 222$-inhibitor group, whereas no significant differences were detected in the miR-221/222-mimic group (Table 3 and Figures 1D,E). These findings, from different perspectives, suggest that the apoptosispromoting effect of radiation can be significantly enhanced by downregulating $m i R-221 / 222$ expression in IOMM-Lee cells.

Further analysis of cell cycle distribution exhibits that the sub-G0/G1 population was positively correlated with radiation dose but negatively correlated with miR-221/222 expression (Table 4, Figures 1F,G). No corresponding effects on the sub$\mathrm{G} 2 / \mathrm{M}$ population were found. Although a significant effect of radiation dose on the $S$ phase population was presented with an interaction with the $m i R-221 / 222$ expression level (Table 2), no obvious radiation dose-dependent trend was explored in pairwise comparisons (Table 3 ).

\section{Radiation Dose and Expression Level of miR-221/222 Antagonistically Modulate IOMM-Lee Cell Invasion}

Increased radiation dose and downregulated $m i R-221 / 222$ have antagonistic effects on cell invasiveness (Tables 1, 2). Pairwise comparison analysis revealed that (1) invasive cell number at 8 Gy was significantly higher than that at lower radiation doses in the control or the scramble group, while invasive cell number at 6 Gy was only significantly higher than that of the unirradiated/2 Gy-irradiated control groups and unirradiated scramble group, respectively; (2) in the $m i R-221 / 222$-mimic group, the invasive cell number for cells irradiated with a dose no lower than 4 Gy was significantly higher than that at lower radiation doses. However, in the $m i R-221 / 222$-inhibitor group, the invasive cell number was significantly increased only in the comparison of 0 vs. 8 Gy (Table 3 and Figure 1H); (3) the expression level of miR-221/222 had no significant effect on cell invasiveness at a low radiation dose $(\leq 2 \mathrm{~Gy})$ compared to that of the control or the scramble group. Only at high radiation doses did the high expression of $m i R-221 / 222$ exhibit a significant invasionpromoting effect $(\geq 4 \mathrm{~Gy})$, while the low expression of $m i R$ $221 / 222$ presented a significant invasion-inhibiting effect ( $\geq 6 \mathrm{~Gy}$ )

(Table 5 and Figure 1H).

By further comparing the invasive cell numbers of the inhibitor group and the control/scramble group exposed to different irradiation doses, it was revealed that although failed to completely reverse the 8 -Gy-promoted invasiveness to a low-dose radiation-induced level, downregulation of $m i R$ 221/222 expression can completely reverse the 6-Gy-induced cell invasiveness to a level, which is without significant increase compared with that of the low-dose-irradiated control groups or unirradiated/low-dose-irradiated scramble groups (Tables 1, 6).

\section{Downregulation of $m i R-221 / 222$ Expression Promotes Radiosensitivity of IOMM-Lee Cells}

The effect of genetic manipulation of $m i R-221 / 222$ on radiosensitivity of IOMM-Lee cells was investigated using a clonogenic assay. The $\mathrm{D}_{0}$ value of the control, scramble, $m i R$ 221/222-mimic, and miR-221/222-inhibitor groups are 5.4242, $5.0970,5.6025$, and $4.1296 \mathrm{~Gy}$, respectively. The sensitization enhancement ratio (SER) was 1.0642, 0.9682, and 1.3135 for the scramble, $m i R-221 / 222$-mimic, and $m i R-221 / 222$-inhibitor groups, respectively (Table 7 , Figure 1J). These results revealed a negative correlation between the SER and the miR-221/222 expression, which provides strong evidence that downregulation of $m i R-221 / 222$ expression can promote the radiosensitivity of IOMM-Lee cells. 

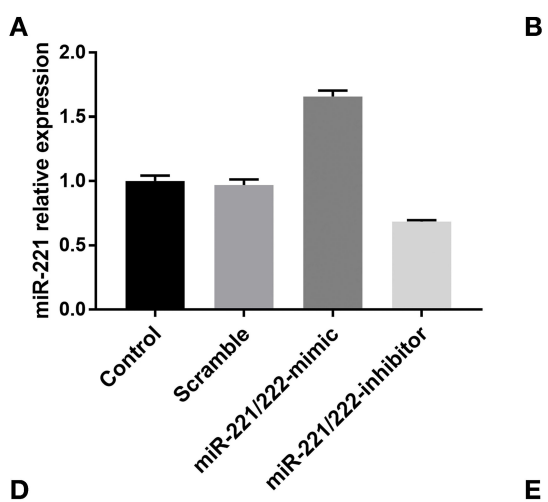

C

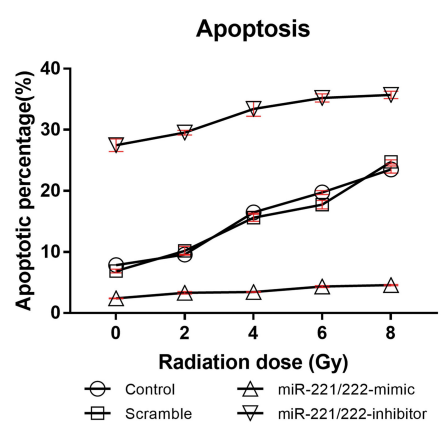

E
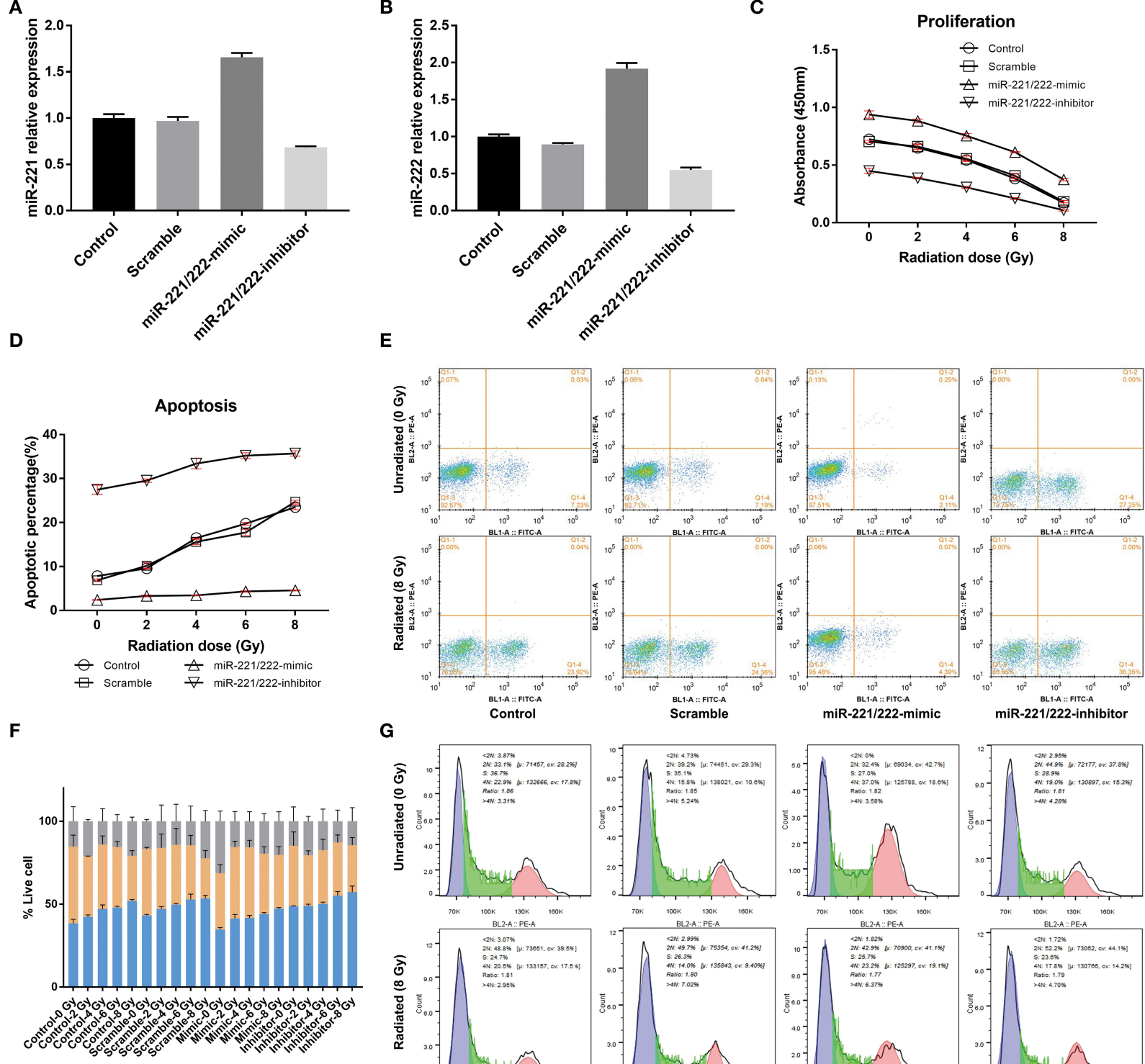

G
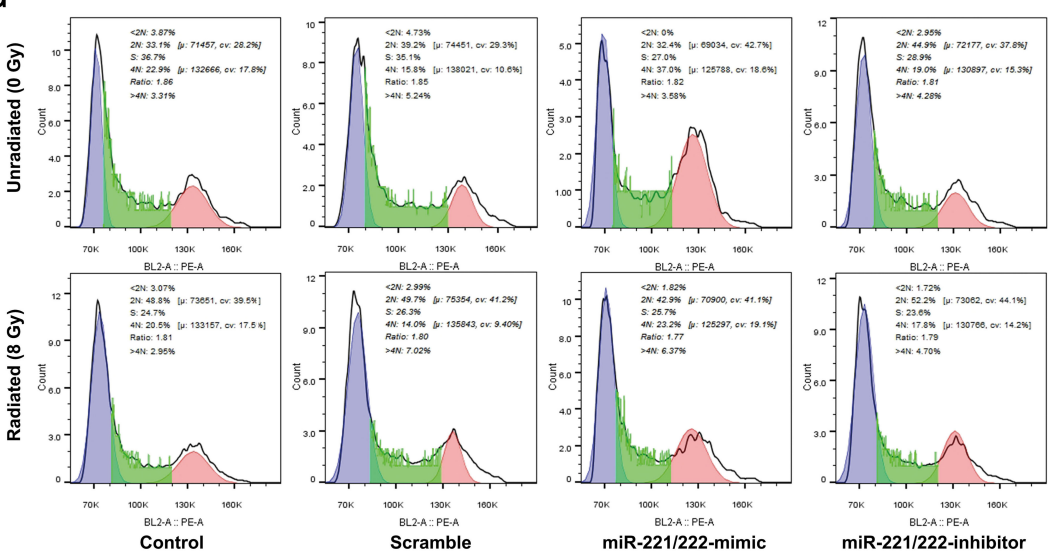

H

Invasiveness
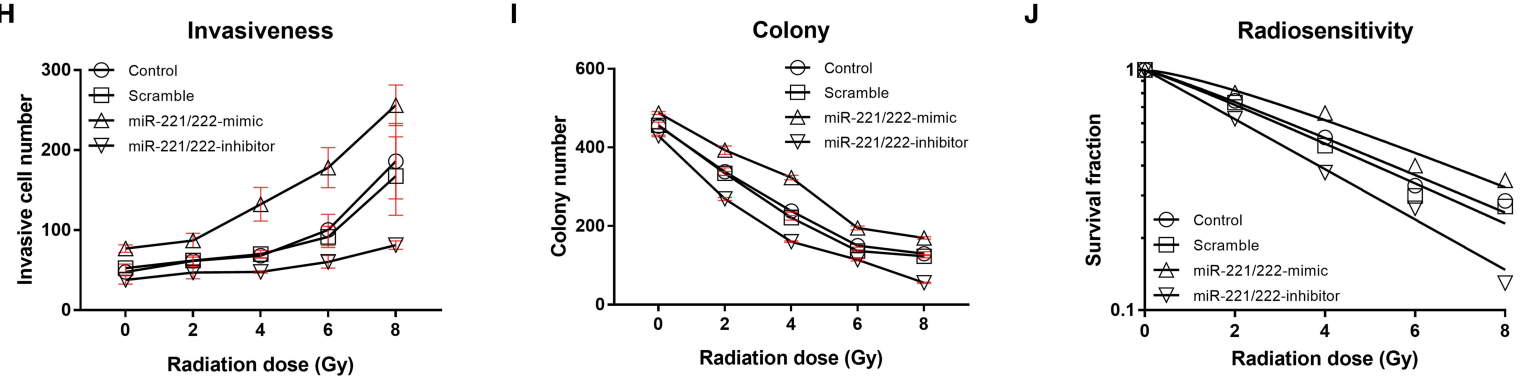

FIGURE 1 | The effects of the expression of miR-221/222 and radiation dose on IOMM-Lee cells in vitro. (A,B) Present the relative expressions of miR-221 and miR-222 in different groups after transfection, respectively. (C) Shows that increasing the radiation dose and downregulating miR-221/222 expression level can synergistically inhibit the proliferation of IOMM-Lee cells, while (D,E) show their synergistical promotion on cell apoptosis. (F,G) Exhibit that both increasing the radiation dose and downregulating miR-221/222 expression level can separately increase the sub-G0/G1 population and induce G0/G1 cell cycle arrest. (H,I) Revealed that increasing the radiation dose and downregulating miR-221/222 expression level can antagonistically regulate the cell invasiveness, while synergistically inhibit the colony formation, respectively. Furthermore, (J) exhibits that downregulating the miR-221/222 expression enhances the radiosensitivity of IOMM-Lee cells. The abovementioned experiments were performed at least in triplicate. 
TABLE 1 | Descriptive statistics of various assays of IOMM-Lee cells.

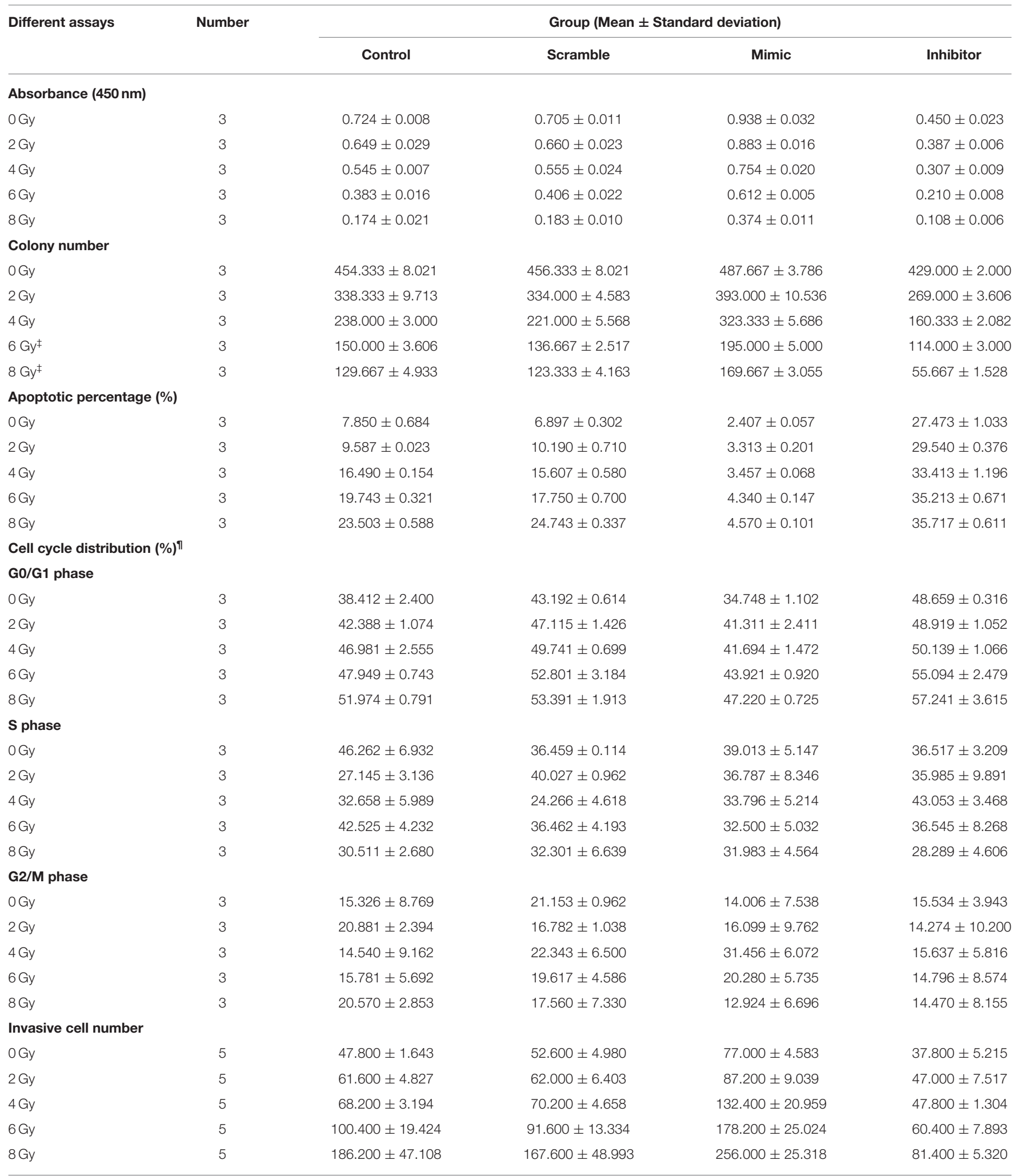

†These results were normalized as the colony numbers per 1000 seeded cells.

"These results, after the exclusion of "< $2 N$ " and "> $4 N$ " parts, were normalized by using the geometric proportion method to achieve the sum of persentages of G0/G1, S, G2/M phases of each subgroup is $100 \%$. 
TABLE 2 | Radiation dose and expression level of miR-221/222 co-modulate IOMM-Lee cells.

\begin{tabular}{|c|c|c|c|c|c|}
\hline Different assays & Source & df & $\boldsymbol{F}$ & $P$ & Partial eta squared \\
\hline \multirow[t]{4}{*}{ Absorbance $(450 \mathrm{~nm})$} & Group & 3 & 1458.879 & $<0.0001^{*}$ & 0.991 \\
\hline & Radiation dose & 4 & 1567.872 & $<0.0001^{*}$ & 0.994 \\
\hline & Group $\times$ Radiation dose & 12 & 19.320 & $<0.0001^{*}$ & 0.853 \\
\hline & Error & 40 & & & \\
\hline \multirow[t]{2}{*}{ Colony number } & Group & 3 & 1032.021 & $<0.0001^{*}$ & 0.987 \\
\hline & Error & 40 & & & \\
\hline \multirow[t]{4}{*}{ Apoptotic percentage } & Group & 3 & 2089.699 & $<0.0001^{*}$ & 0.998 \\
\hline & Radiation dose & 4 & 238.783 & $<0.0001^{*}$ & 0.988 \\
\hline & Group $\times$ Radiation dose & 12 & 26.278 & $0.0038^{*}$ & 0.963 \\
\hline & Error & 40 & & & \\
\hline & Group $\times$ Radiation dose & 12 & 1.870 & 0.0691 & 0.359 \\
\hline & Error & 40 & & & \\
\hline \multirow[t]{4}{*}{ S phase } & Group & 3 & 0.511 & 0.6767 & 0.037 \\
\hline & Radiation dose & 4 & 4.643 & $0.0036^{\star}$ & 0.317 \\
\hline & Group $\times$ Radiation dose & 12 & 3.256 & $0.0024^{*}$ & 0.494 \\
\hline & Error & 40 & & & \\
\hline \multirow[t]{4}{*}{ G2/M phase } & Group & 3 & 1.406 & 0.2551 & 0.095 \\
\hline & Radiation dose & 4 & 0.982 & 0.4283 & 0.089 \\
\hline & Group $\times$ Radiation dose & 12 & 1.297 & 0.2584 & 0.280 \\
\hline & Error & 40 & & & \\
\hline Invasive cell number & Group & 3 & 97.670 & $<0.0001^{\star}$ & 0.786 \\
\hline
\end{tabular}

*Indicates statistical significance, and relevant $P$ values are emphasized in bold.

\section{PTEN Is a Target Gene of the $m i R-221 / 222$ Cluster}

Dual luciferase reporter assay revealed that cotransfection of miR-221 or miR-222 mimics with psi-check2-PTEN significantly decreased luciferase activity compared to scramble or controltreated cells (miR-221: $P<0.0001 ; m i R-222: P<0.0001)$ (Figures 2A,B). Western blot analysis showed that PTEN was upregulated gradually as the miR-221/222 expression level decreased or the radiation dose increased (Figures 2C,D). All these data demonstrated that PTEN is a target gene of the miR-221/222 cluster.

\section{Downregulation of $m i R-221 / 222$ Expression and Irradiation Suppress Tumor Growth in vivo}

Dramatic reductions in tumor volume were observed in irradiated control (38.66\%), scramble (38.56\%), miR-221/222mimic (33.78\%), and $m i R-221 / 222$-inhibitor (20.08\%) groups as compared with their respective unirradiated counterparts
(Figure 3), indicating a significant inhibitory effect of irradiation on the volume of subcutaneous IOMM-Lee xenografts in nude mice $\left(P<0.0001\right.$, partial $\left.\eta^{2}=0.474\right)$. For unirradiated animals, tumor volume in the $m i R-221 / 222$-inhibitor group decreased by $85.21,80.38$, and $90.15 \%$ as compared with the control, scramble, and miR-221/222-mimic groups. The corresponding reduction rates in irradiation groups were $80.74,74.48$, and $88.11 \%$. These suggest that the tumor volume can be suppressed by inhibiting the expression of miR-221/222 in vivo $(P<0.0001$, partial $\eta^{2}=0.862$ ). Furthermore, these two treatments have a synergistic effect on preventing tumor growth in vivo $(P=0.002$, partial $\eta^{2}=0.232$ ).

In addition to further proving these abovementioned results, multiple comparisons of tumor volumes at the last measure also revealed that no significant difference between the radiated-mimics group and the unradiated-control or unradiated-scramble group, indicating the antagonistic effect between radiation and upregulated miR-221/222 expression in vivo (Table 8). A same situation was also found in the comparison between the unradiated-inhibitor group and the 
TABLE 3 | Pairwise comparisons between IOMM-Lee cells irradiated with different dosages in various assays.

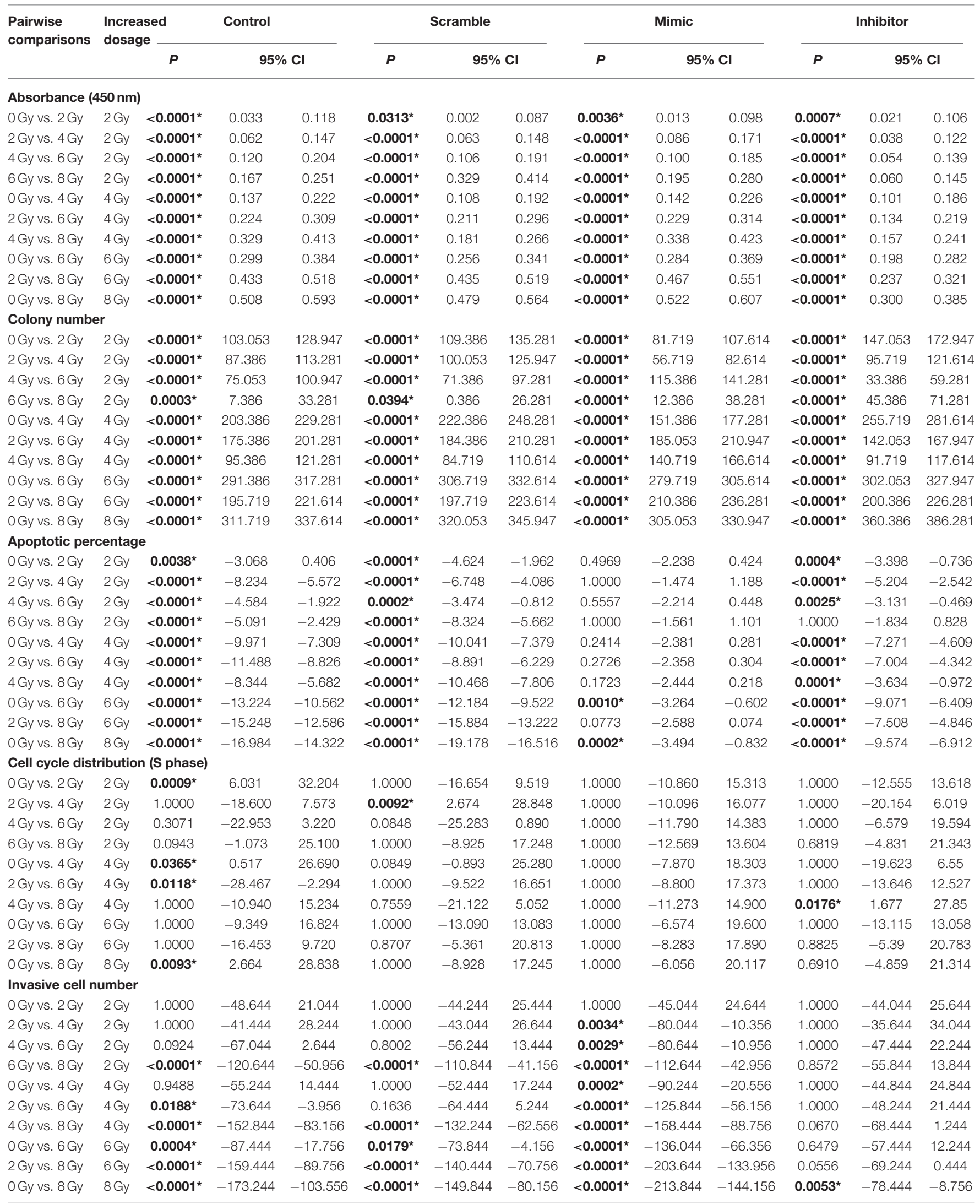

*Indicates statistical significance, and relevant $P$ values are emphasized in bold. 
TABLE 4 | Multiple comparisons of the persentage of G0/G1 phase between different IOMM-Lee cell groups.

\begin{tabular}{|c|c|c|c|}
\hline \multirow{2}{*}{$\begin{array}{l}\text { Multiple comparisons } \\
\text { o Gy vs. } 2 \text { Gy }\end{array}$} & \multirow{2}{*}{$\begin{array}{c}P \\
0.0001^{\star}\end{array}$} & \multicolumn{2}{|c|}{$95 \% \mathrm{Cl}$} \\
\hline & & -5.841 & -1.520 \\
\hline 2 Gy vs. 4 Gy & $0.0423^{\star}$ & -4.366 & -0.045 \\
\hline 4 Gy vs. 6 Gy & $0.0041^{*}$ & -4.963 & -0.642 \\
\hline 6 Gy vs. 8 Gy & $0.0130^{*}$ & -4.676 & -0.355 \\
\hline O Gy vs. 4 Gy & $<0.0001^{*}$ & -8.046 & -3.726 \\
\hline 2 Gy vs. 6 Gy & $<0.0001^{*}$ & -7.169 & -2.848 \\
\hline 4 Gy vs. 8 Gy & $<0.0001^{*}$ & -7.478 & -3.157 \\
\hline 0 Gy vs. 6 Gy & $<0.0001^{*}$ & -10.849 & -6.528 \\
\hline 2 Gy vs. 8 Gy & $<0.0001^{*}$ & -9.684 & -5.363 \\
\hline O Gy vs. 8 Gy & $<0.0001^{\star}$ & -13.364 & -9.043 \\
\hline Control vs. Scramble & $<0.0001^{*}$ & -5.512 & -1.902 \\
\hline Mimic vs. Control & $<0.0001^{\star}$ & -5.567 & -1.957 \\
\hline Mimic vs. Scramble & $<0.0001^{*}$ & -9.274 & -5.664 \\
\hline Inhibitor vs. Control & $<0.0001^{*}$ & 4.664 & 8.275 \\
\hline Inhibitor vs. Scramble & $0.0008^{*}$ & 0.957 & 4.568 \\
\hline Mimic vs. Inhibitor & $<0.0001^{*}$ & -12.037 & -8.426 \\
\hline
\end{tabular}

*Indicates statistical significance, and relevant $P$ values are emphasized in bold.

radiated-inhibitor group (Table 8). This may be explained by the observation that the effect of inhibiting the miR-221/222 expression on preventing tumor progression has already been too obvious to reflect the effect of radiation.

\section{Downregulation of $m i R-221 / 222$ Expression and Irradiation Promote the Expression of PTEN in vivo}

Immunohistochemical analysis of tissue sections of xenografts reflects a gradually increased immunoreactivity of PTEN as the miR-221/222 expression decreases (Figure 4); meanwhile, tissue sections from radiation-treated xenografts exhibited higher expression levels of PTEN compared to their corresponding unirradiated counterparts (Figure 4). These are consistent with the results of in vitro studies.

\section{DISCUSSION}

In the present study, both radiation dose and expression level of miR-221/222 significantly contributed to the regulation of the proliferation, colony formation, apoptosis, invasiveness, and subcutaneous xenografts of IOMM-Lee cells with significant interactions present, whereas they significantly regulated the sub-G0/G1 population without an interaction (Table 2). Increasing the radiation dose and downregulating $m i R-221 / 222$ expression level can synergistically inhibit the proliferation and colony formation, prevent subcutaneous xenografts progression, and promote the apoptosis of IOMMLee cells, while they antagonistically regulate the cell invasion (Tables 1, 2, 8 and Figures 1, 3). In addition, inhibiting the $m i R-221 / 222$ expression in IOMM-Lee cell can promote its radiosensitivity (Table 7 ). Consequently, downregulating the expression level of $m i R-221 / 222$ can promote the strengths of radiation and circumvent its weaknesses in IOMM-Lee cell treatment.

\section{Paradoxical Effects of lonizing Radiation on IOMM-Lee Cells}

The radiation dose-dependent apoptosis-promoting and proliferation-inhibiting effects of radiation on IOMM-Lee cells provide theoretical bases for utilizing postoperative radiation therapy to control the growth of residual or recurrent meningiomas in the clinic (Tables 1-3, 8, Figures 1C-E, 3). However, the radiation-induced invasiveness of IOMM-Lee cells may explain the unsatisfactory recurrence-free survival or even some toxicities of clinical adjuvant radiotherapy (Tables 1-3 and Figure 1H).

It has been revealed in several cancer cells (including breast, lung, and liver cancer, and glioma cells) that ionizing radiation (IR) enhances their migratory and invasive properties by inducing the epithelial-mesenchymal transition (EMT) (3540). This IR-induced EMT is mediated by EMT-inducing transcription factors (EMT-TFs) (e.g., Snail, ZEB, and Twist families) that are activated by a network of signaling pathways (41-44). These EMT-TFs possess two potentials in cancer cells: (1) prometastatic potential-the aforementioned IR-enhanced migration and invasiveness reflect their prometastatic role. They regulate the expression level of proteins that is implicated in cell polarity, cytoskeletal structural maintenance, cellcell contact, and extracellular matrix degradation, and they suppress key epithelial genes (e.g., E-cadherin) (41-44); (2) oncogenic potential: they are implicated in inducing malignant transformation $(41,45)$, stemness properties $(41,45)$, and oncogenic metabolism $(41,44)$. Hence, it is logical to assume that the present radiation-enhanced invasiveness of IOMMLee cells may be caused by the IR-induced EMT. In addition, we revealed in our previous clinical study that malignant progressed atypical meningiomas are more likely to exhibit low connexin 43 expression in their preradiotherapeutic tissues (46). Malignant transformation is one of the toxicities of radiotherapy in meningiomas (2). Connexin 43, the most abundant connexin isoform in the central nervous system $(47,48)$, oligomerizes to form gap junctions between adjacent meningioma cells $(49,50)$. These two points, as well as the present radiation-induced invasiveness of IOMM-Lee cells, all correspond to the prometastatic and oncogenic capacities of EMT-TFs. Al-Mefty et.al discovered the same complex genetic alterations that they saw in histologically highergrade meningiomas already apparent in the early, benign stages of those tumors (51). Arishima et al. reported that different subtypes of meningiomas express different levels of connexin 43 (52). These findings raises the possibility that meningioma cells' inherent expression levels of certain moleculars and the intrinsic regulation level of EMT-TFs may determine whether this meningioma will undergo invasiveness enhancement, tumor recurrence, or malignant progression after radiotherapy. 
TABLE 5 | Pairwise comparisons between IOMM-Lee cells with different miR-221/222 expression levels in various assays.

\begin{tabular}{|c|c|c|c|c|c|c|c|c|c|c|c|c|c|c|c|}
\hline \multirow[t]{2}{*}{ Pairwise comparisons } & \multicolumn{3}{|c|}{0 Gy } & \multicolumn{3}{|c|}{2 Gy } & \multicolumn{3}{|c|}{4 Gy } & \multicolumn{3}{|c|}{6 Gy } & \multicolumn{3}{|c|}{8 Gy } \\
\hline & $\boldsymbol{P}$ & \multicolumn{2}{|c|}{$95 \% \mathrm{Cl}$} & \multicolumn{3}{|c|}{$95 \% \mathrm{Cl}$} & \multicolumn{3}{|c|}{$95 \% \mathrm{Cl}$} & \multicolumn{3}{|c|}{$95 \% \mathrm{Cl}$} & \multicolumn{3}{|c|}{$95 \% \mathrm{Cl}$} \\
\hline \multicolumn{16}{|l|}{ Absorbance $(450 \mathrm{~nm})$} \\
\hline Control vs. Scramble & 1.0000 & -0.020 & 0.059 & 1.0000 & -0.050 & 0.028 & 1.0000 & -0.049 & 0.029 & 0.6205 & -0.063 & 0.016 & 1.0000 & -0.049 & 0.030 \\
\hline Mimic vs. Control & $<0.0001^{\star}$ & 0.175 & 0.253 & $<0.0001^{*}$ & 0.195 & 0.273 & $<0.0001^{\star}$ & 0.170 & 0.249 & $<0.0001^{\star}$ & 0.190 & 0.268 & $<0.0001^{*}$ & 0.161 & 0.240 \\
\hline Mimic vs. Scramble & $<0.0001^{*}$ & 0.194 & 0.273 & $<0.0001^{\star}$ & 0.184 & 0.262 & $<0.0001^{\star}$ & 0.160 & 0.239 & $<0.0001^{\star}$ & 0.166 & 0.245 & $<0.0001^{*}$ & 0.152 & 0.230 \\
\hline Inhibitor vs. Control & $<0.0001^{*}$ & -0.314 & -0.235 & $<0.0001^{*}$ & -0.302 & -0.223 & $<0.0001^{*}$ & -0.277 & -0.199 & $<0.0001^{\star}$ & -0.212 & -0.133 & $0.0002^{*}$ & -0.105 & -0.027 \\
\hline Inhibitor vs. Scramble & $<0.0001^{*}$ & -0.294 & -0.215 & $<0.0001^{*}$ & -0.313 & -0.234 & $<0.0001^{*}$ & -0.287 & -0.209 & $<0.0001^{*}$ & -0.236 & -0.157 & $<0.0001^{*}$ & -0.115 & -0.036 \\
\hline Mimic vs. Inhibitor & $<0.0001^{*}$ & 0.449 & 0.528 & $<0.0001^{*}$ & 0.457 & 0.536 & $<0.0001^{*}$ & 0.408 & 0.487 & $<0.0001^{*}$ & 0.362 & 0.441 & $<0.0001^{*}$ & 0.227 & 0.306 \\
\hline \multicolumn{16}{|l|}{ Colony number } \\
\hline Control vs. Scramble & 1.0000 & -14.096 & 10.096 & 1.0000 & -7.763 & 16.430 & $0.0021^{*}$ & 4.904 & 29.096 & $0.0237^{*}$ & 1.237 & 25.430 & 0.9235 & -5.763 & 18.430 \\
\hline Mimic vs. Control & $<0.0001^{*}$ & 21.237 & 45.430 & $<0.0001^{*}$ & 42.570 & 66.763 & $<0.0001^{*}$ & 73.237 & 97.430 & $<0.0001^{*}$ & 32.904 & 57.096 & $<0.0001^{*}$ & 27.904 & 52.096 \\
\hline Mimic vs. Scramble & $<0.0001^{*}$ & 19.237 & 43.430 & $<0.0001^{*}$ & 46.904 & 71.096 & $<0.0001^{*}$ & 90.237 & 114.430 & $<0.0001^{*}$ & 46.237 & 70.430 & $<0.0001^{*}$ & 34.237 & 58.430 \\
\hline Inhibitor vs. Control & $<0.0001^{*}$ & -37.430 & -13.237 & $<0.0001^{*}$ & -81.430 & -57.237 & $<0.0001^{*}$ & -89.763 & -65.570 & $<0.0001^{*}$ & -48.096 & -23.904 & $<0.0001^{*}$ & -86.096 & -61.904 \\
\hline Inhibitor vs. Scramble & $<0.0001^{*}$ & -39.430 & -15.237 & $<0.0001^{*}$ & -77.096 & -52.904 & $<0.0001^{*}$ & -72.763 & -48.570 & $<0.0001^{\star}$ & -34.763 & -10.570 & $<0.0001^{*}$ & -79.763 & -55.570 \\
\hline Mimic vs. Inhibitor & $<0.0001^{\star}$ & 46.570 & 70.763 & $<0.0001^{\star}$ & 111.904 & 136.096 & $<0.0001^{*}$ & 150.904 & 175.096 & $<0.0001^{*}$ & 68.904 & 93.096 & $<0.0001^{*}$ & 101.904 & 126.096 \\
\hline \multicolumn{16}{|l|}{ Apoptotic percentage } \\
\hline Control vs. Scramble & 0.2373 & -0.290 & 2.197 & 1.0000 & -1.847 & 0.640 & 0.3334 & -0.360 & 2.127 & $0.0004^{*}$ & 0.750 & 3.237 & 0.0510 & -2.484 & 0.004 \\
\hline Mimic vs. Control & $<0.0001^{*}$ & -6.687 & -4.200 & $<0.0001^{*}$ & -7.517 & -5.030 & $<0.0001^{*}$ & -14.277 & -11.790 & $<0.0001^{\star}$ & -16.647 & -14.160 & $<0.0001^{*}$ & -20.177 & -17.690 \\
\hline Mimic vs. Scramble & $<0.0001^{*}$ & -5.734 & -3.246 & $<0.0001^{*}$ & -8.120 & -5.633 & $<0.0001^{*}$ & -13.394 & -10.906 & $<0.0001^{*}$ & -14.654 & -12.166 & $<0.0001^{*}$ & -21.417 & -18.930 \\
\hline Inhibitor vs. Control & $<0.0001^{*}$ & 18.380 & 20.867 & $<0.0001^{*}$ & 18.710 & 21.197 & $<0.0001^{*}$ & 15.680 & 18.167 & $<0.0001^{*}$ & 14.226 & 16.714 & $<0.0001^{*}$ & 10.970 & 13.457 \\
\hline Inhibitor vs. Scramble & $<0.0001^{*}$ & 19.333 & 21.820 & $<0.0001^{*}$ & 18.106 & 20.594 & $<0.0001^{*}$ & 16.563 & 19.050 & $<0.0001^{*}$ & 16.220 & 18.707 & $<0.0001^{*}$ & 9.730 & 12.217 \\
\hline Mimic vs. Inhibitor & $<0.0001^{*}$ & -26.310 & -23.823 & $<0.0001^{*}$ & -27.470 & -24.983 & $<0.0001^{*}$ & -31.200 & -28.713 & $<0.0001^{*}$ & -32.117 & -29.630 & $<0.0001^{*}$ & -32.390 & -29.903 \\
\hline \multicolumn{16}{|l|}{ Invasive cell number } \\
\hline Control vs. Scramble & 1.0000 & -37.453 & 27.853 & 1.0000 & -33.053 & 32.253 & 1.0000 & -34.653 & 30.653 & 1.0000 & -23.853 & 41.453 & 0.7634 & -14.053 & 51.253 \\
\hline Mimic vs. Control & 0.1069 & -3.453 & 61.853 & 0.2221 & -7.053 & 58.253 & $<0.0001^{*}$ & 31.547 & 96.853 & $<0.0001^{*}$ & 45.147 & 110.453 & $<0.0001^{*}$ & 37.147 & 102.453 \\
\hline Mimic vs. Scramble & 0.2793 & -8.253 & 57.053 & 0.2399 & -7.453 & 57.853 & $<0.0001^{*}$ & 29.547 & 94.853 & $<0.0001^{*}$ & 53.947 & 119.253 & $<0.0001^{*}$ & 55.747 & 121.053 \\
\hline Inhibitor vs. Control & 1.0000 & -42.653 & 22.653 & 1.0000 & -47.253 & 18.053 & 0.5693 & -53.053 & 12.253 & $0.0083^{\star}$ & -72.653 & -7.347 & $<0.0001^{*}$ & -137.453 & -72.147 \\
\hline Inhibitor vs. Scramble & 1.0000 & -47.453 & 17.853 & 1.0000 & -47.653 & 17.653 & 0.4029 & -55.053 & 10.253 & 0.0693 & -63.853 & 1.453 & $<0.0001^{*}$ & -118.853 & -53.547 \\
\hline Mimic vs. Inhibitor & $0.0102^{\star}$ & 6.547 & 71.853 & $0.0079^{\star}$ & 7.547 & 72.853 & $<0.0001^{*}$ & 51.947 & 117.253 & $<0.0001^{*}$ & 85.147 & 150.453 & $<0.0001^{*}$ & 141.947 & 207.253 \\
\hline
\end{tabular}

*Indicates statistical significance, and relevant $P$ values are emphasized in bold. 


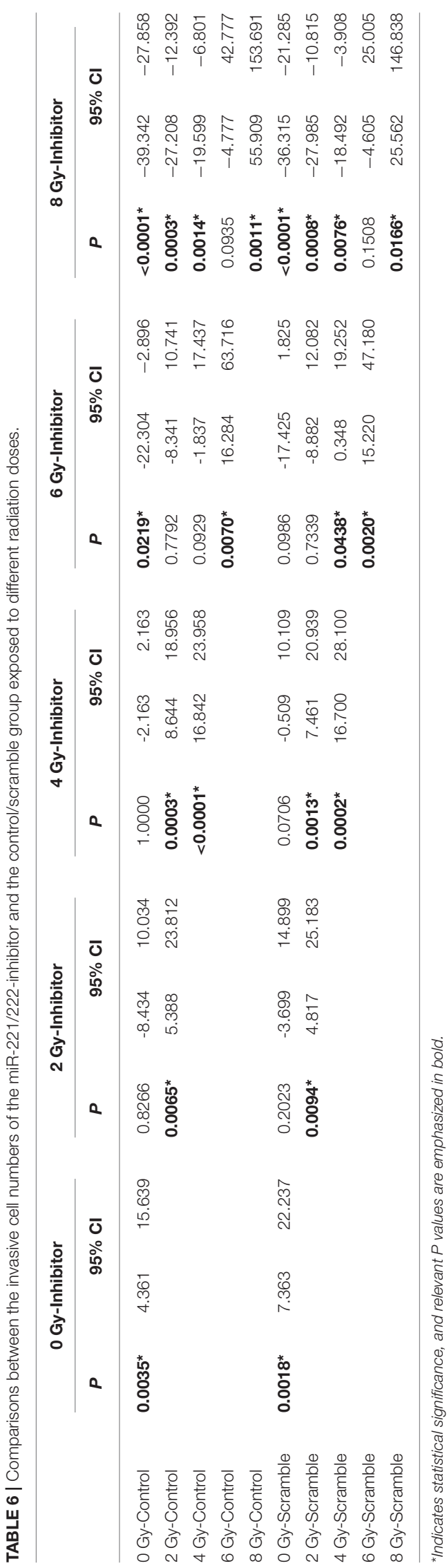

TABLE 7 | Impact of miRNA-221/222 expression on IOMM-Lee cell radiosensitivity.

\begin{tabular}{lcccc}
\hline Group & $\mathbf{D}_{\mathbf{0}}$ & $\mathbf{D q}$ & $\mathbf{S F}_{\mathbf{2}}$ & SER \\
\hline Control + irradiation & 5.4242 & 0.6797 & 0.7364 & \\
Scramble + irradiation & 5.0970 & 0.5713 & 0.7160 & 1.0642 \\
miRNA-221/222-mimic + irradiation & 5.6025 & 2.0211 & 0.8220 & 0.9682 \\
miRNA-221/222-inhibitor + irradiation & 4.1296 & 0.1000 & 0.6250 & 1.3135
\end{tabular}

$D_{0}$ is a dose that reduces the survival fraction from $100 \%$ to $37 \%$; Dq, quasi-threshold dose; SF2, survival fraction at 2 Gy; SER, the sensitization enhancement ratio.

\section{Downregulation of $m i R-221 / 222$ Expression Enhances the Apoptosis-Promoting Effect and Proliferation-Inhibiting Effect of Radiation and Promotes Radiosensitivity of IOMM-Lee Cells}

The radiosensitization of downregulating the miR-221/222 cluster has been certified in several human tumors: Zhang et al. successively discovered that tumor radiosensitivity could be promoted by the knockdown of $m i R-221$ and $m i R-222$ in gastric cancer cell line SGC7901 (31) and glioblastoma cell line U251, and demonstrated that PTEN is a target gene of the miR-221/222 cluster (31); Sun and Khoshinani confirmed that $m i R-221$ (33) and miR-222 (32) mediated the radiosensitivity of colorectal cancer cells by regulating PTEN, respectively; consistent results were reported by $\mathrm{Wu}$ and his colleague in their study of nasopharyngeal carcinoma (34). The radiosensitivity enhancement of $m i R-221 / 222$ downregulation and PTEN as the target gene of these two miRNAs were also confirmed in our present study of IOMM-Lee meningioma cells.

The PTEN gene, located at 10q23.3, was identified as one of the most commonly mutated tumor suppressor in human cancers, second only to p53 (53). Its encoded PTEN protein exhibits phosphoinositide 3-phosphatase activity toward phosphatidylinositol 3,4,5-trisphosphate and antagonizes phosphatidylinositol 3-kinase (PI3K) functions to negatively regulate cell proliferation and promote cell apoptosis (54). Loss-of-function mutations in the PTEN gene result in the inactivation of the PTEN protein, which further gives rise to oncogenic transformation of cells, resistance, and relapse in response to conventional therapeutic agents $(55,56)$.

IR exerts its therapeutic effect mainly by generating DNA damages (57). These IR-induced DNA damages, primarily double-strand breaks, trigger a number of DNA damage response and repair signaling cascades and subsequently phosphorylate p53 protein (58-61). Activated p53 upregulates the transcriptional and translational levels of several genes (including PTEN) to cause cell cycle arrest, apoptosis, autophagy, or senescence according to the severity of the DNA damage and the cell type $(42,62-65)$. Meanwhile, accumulation of PTEN, in turn, remarkably enhances p53 DNA binding and transcriptional activity by interacting with its C-terminal domain (66). Briefly, IR can induce PTEN 
A

miR-221

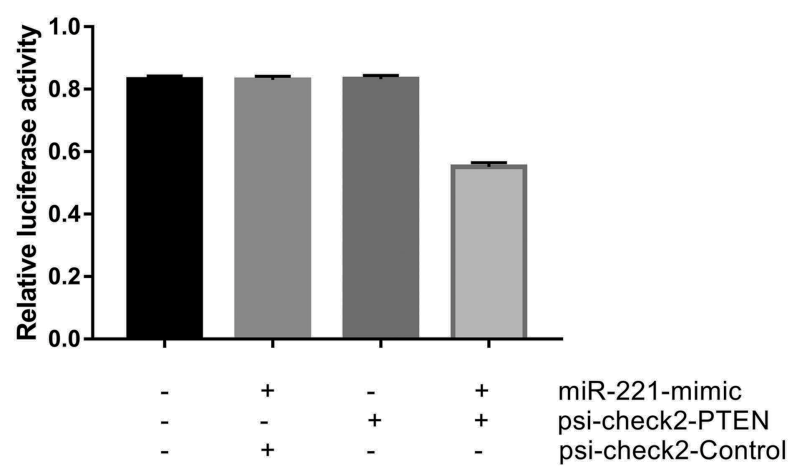

C
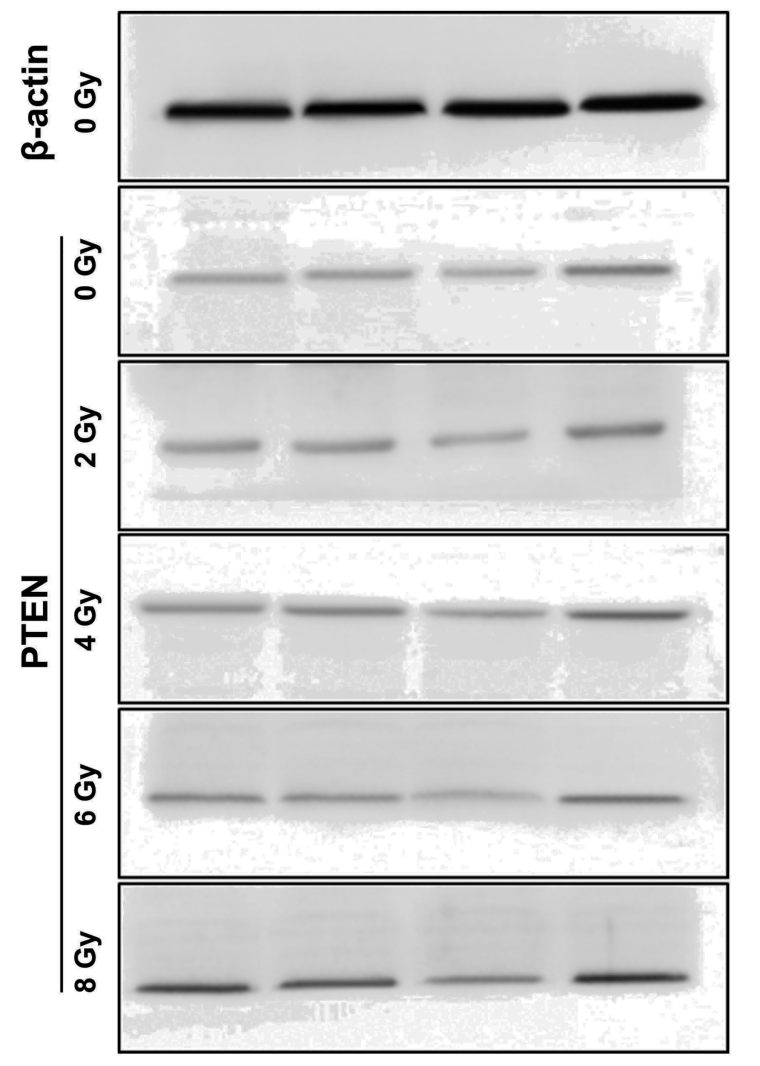

Control Scramble Mimics Inhibitor
B

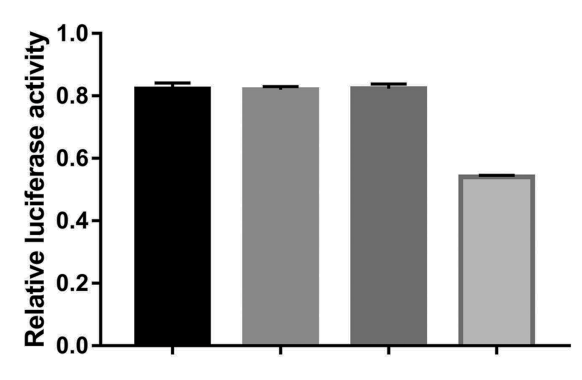

$\begin{array}{lllll}- & + & - & + & \text { miR-222-mimic } \\ - & - & + & + & \text { psi-check2-PTEN } \\ - & + & - & - & \text { psi-check2-Control }\end{array}$

D

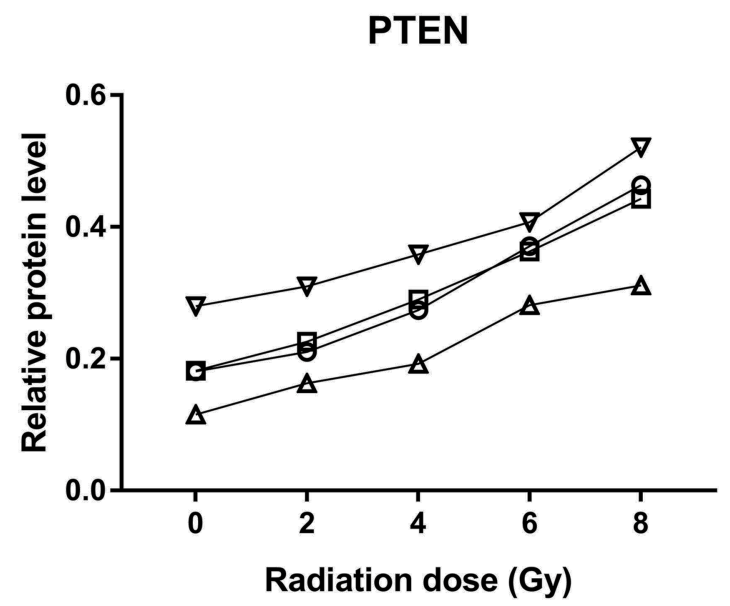

$\begin{array}{lll}\text { ๑ C Control } & \Delta \text { miR221/222-mimic } \\ \square-\text { Scramble } & \boldsymbol{\nabla} \text { miR221/222-inhibitor }\end{array}$

FIGURE 2 | Phosphatase and tensin homolog (PTEN) is a target gene of miR-221 and miR-222 in IOMM-Lee cells. (A,B) Significantly decreased luciferase activities were revealed after the cotransfection of miR-221 mimics or miR-222 mimics and psi-check2-PTEN in dual luciferase reporter assay. (C,D) Western blot analysis exhibited that the expression of PTEN was positively correlated with radiation dose but negatively correlated with miR-221/222 expression.

accumulation to facilitate its therapeutic effects in some tumors. H460 cells obtained enhanced PTEN expression after irradiation in Il Lae Jung's previous research of nonsmall cell lung cancer (67). Similarly, the present radiation dose-dependent increase in PTEN in the IOMM-Lee cells suggests that the abovementioned mechanisms were activated during radiotherapy in meningiomas. Moreover, improved radiotherapeutic response in meningiomas can be achieved by further upregulation of PTEN through inhibiting the miR-221/222 expression.

The radiosensitization of PTEN has also been reported in previous literature: Rosser et al. identified forced expression of PTEN as a valuable approach to achieve radiosensitization in prostate cancer cells (68); multiple studies confirmed that the radioresistance of nasopharyngeal carcinoma could be enhanced by suppressing the expression of PTEN (69-71); consistent 
A

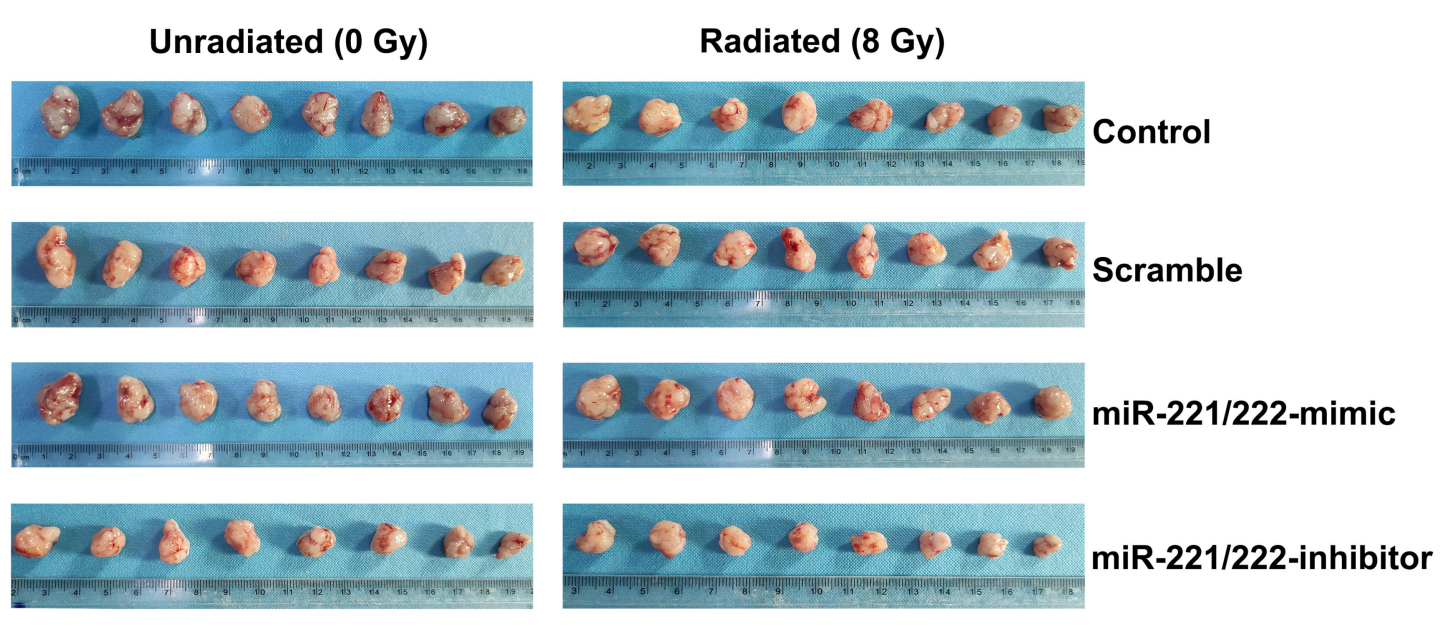

B

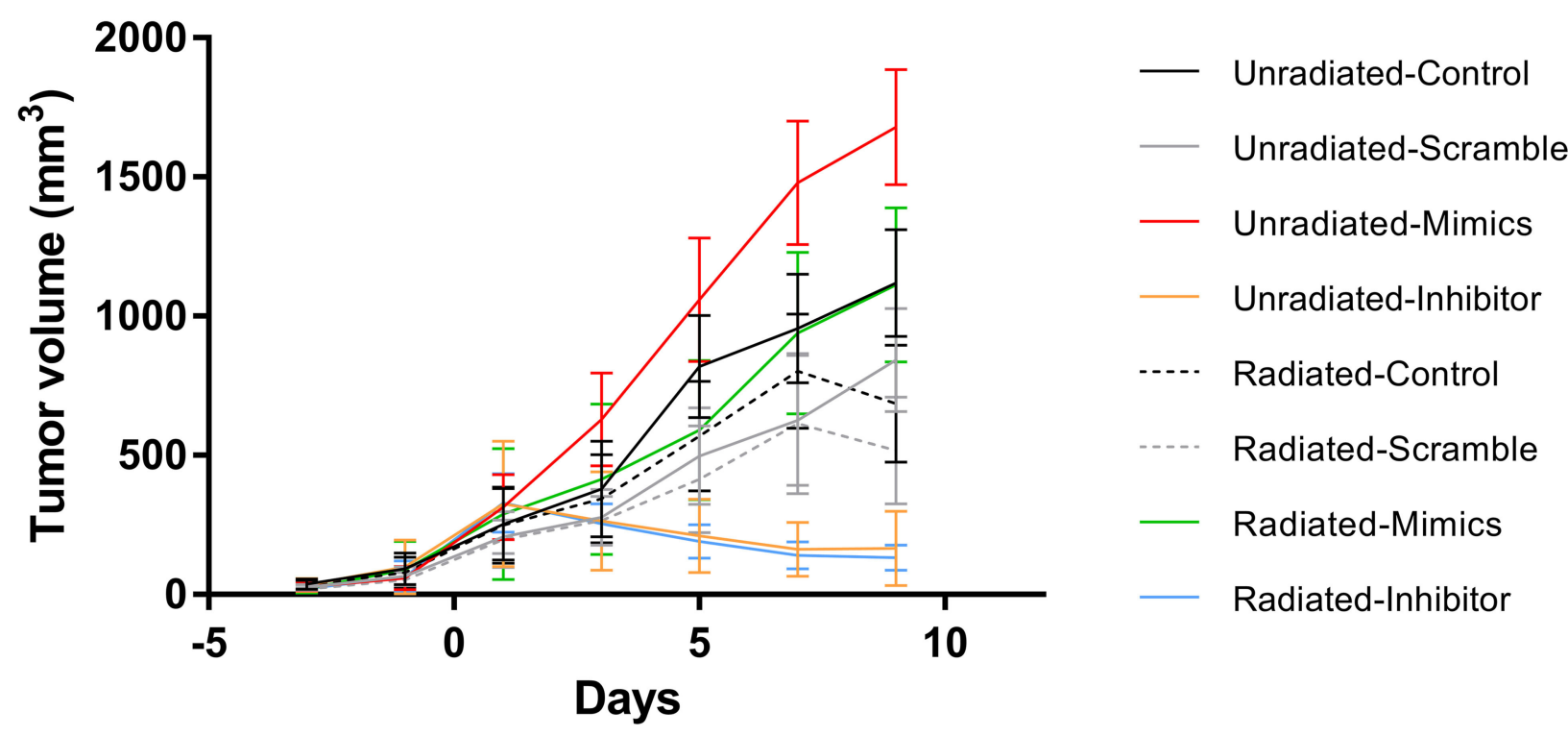

FIGURE 3 | Downregulating miR-221/222 expression along with radiation suppresses subcutaneous tumor growth in vivo. (A) Exhibits the xenograft tumors from different treatment subgroups. (B) Reveals that both inhibition of the miR-221/222 expression level and ionizing radiation significantly suppress tumor growth in nude mice.

conclusions were obtained in the corresponding researches of non-small cell lung carcinoma (72), hepatocellular carcinoma (73), and esophageal cancer (74). Accordingly, the present observations indicate that the radiosensitization of $m i R-221 / 222$ inhibition in IOMM-Lee cells was achieved by its further upregulation of PTEN expression on the basis of IR-induced PTEN accumulation.

\section{Downregulation of $m i R-221 / 222$ Expression Can Reverse Radiation-Induced Cell Invasiveness}

The IR-induced invasiveness of IOMM-Lee cells enhanced significantly as radiation dosage increased. Downregulation of
miR-221/222 could promote the expression of PTEN and reverse the IR-enhanced cell invasiveness. As previously described, the IR-enhanced cell invasiveness is associated with EMT. Aside from their abovementioned radiosensitivity-regulatory effect, $m i R-221$ and $m i R-222$ have also been revealed to promote EMT (75) and increase migration and invasion in several other tumors (76). As a target of the miR-221/222 cluster, PTEN has been verified to possess the ability of reversing EMT in Jin's radioresistant esophageal cancer cells study (74). Therefore, it is conceivable that miR-221/222 downregulation reverses the radiation-induced cell invasiveness and is achieved by the EMTreversion effect of accumulated PTEN. However, the underlying mechanisms of PTEN-regulated EMT in meningiomas require further investigations. 
TABLE 8 | Time-varing tumor volumes of IOMM-Lee xenograft tumors in various treatment groups.

\begin{tabular}{|c|c|c|c|c|c|c|c|c|c|}
\hline \multirow[t]{2}{*}{ Days } & \multirow[t]{2}{*}{ Description } & \multicolumn{4}{|c|}{ Unradiated groups (Mean \pm Standard deviation) } & \multicolumn{4}{|c|}{ Radiated GROUPS (Mean \pm Standard deviation) } \\
\hline & & Control & Scramble & Mimics & Inhibitor & Control & Scramble & Mimics & Inhibitor \\
\hline-3 & 1st Pre-treat & $37.046 \pm 18.881$ & $25.701 \pm 10.108$ & $27.921 \pm 13.966$ & $34.697 \pm 23.985$ & $32.867 \pm 18.433$ & $18.493 \pm 5.085$ & $20.396 \pm 15.011$ & $20.432 \pm 15.302$ \\
\hline-1 & 2nd Pre-treat & $92.979 \pm 57.307$ & $65.933 \pm 33.077$ & $59.935 \pm 42.045$ & $99.533 \pm 97.297$ & $78.893 \pm 55.275$ & $52.566 \pm 25.984$ & $89.624 \pm 103.919$ & $64.602 \pm 57.082$ \\
\hline 0 & 1st -injection & & & & & & & & \\
\hline 1 & 1st-measure & $252.025 \pm 129.423$ & $207.469 \pm 60.287$ & $313.998 \pm 116.227$ & $325.252 \pm 224.913$ & $248.363 \pm 137.236$ & $198.245 \pm 100.424$ & $288.830 \pm 235.379$ & $329.696 \pm 104.858$ \\
\hline 2 & 1 st $-\mathrm{IR}$ & & & & & & & & \\
\hline 3 & 2nd-measure & $378.611 \pm 171.727$ & $277.653 \pm 100.420$ & $628.602 \pm 167.446$ & $264.124 \pm 176.213$ & $344.355 \pm 158.887$ & $266.415 \pm 88.061$ & $414.844 \pm 269.869$ & $253.916 \pm 71.315$ \\
\hline 4 & 2nd -injection & & & & & & & & \\
\hline 5 & 3rd-measure & $819.921 \pm 184.435$ & $497.531 \pm 173.248$ & $1059.213 \pm 222.273$ & $211.468 \pm 132.266$ & $569.421 \pm 196.957$ & $414.461 \pm 192.684$ & $590.938 \pm 250.908$ & $190.157 \pm 60.905$ \\
\hline 6 & 2nd -IR & & & & & & & & \\
\hline 7 & 4th-measure & $956.500 \pm 195.499$ & $626.219 \pm 233.596$ & $1478.570 \pm 223.009$ & $162.200 \pm 97.474$ & $801.723 \pm 206.409$ & $613.421 \pm 252.433$ & $939.645 \pm 290.516$ & $140.574 \pm 47.782$ \\
\hline 8 & 3rd -injection & & & & & & & & \\
\hline 9 & 5th-measure & $1118.742 \pm 191.996$ & $843.166 \pm 185.583$ & $1679.081 \pm 206.211$ & $165.412 \pm 134.343$ & $686.242 \pm 211.075$ & $518.079 \pm 192.757$ & $1111.826 \pm 277.750$ & $132.189 \pm 44.762$ \\
\hline \multicolumn{10}{|c|}{ Multiple comparisons (the 5th-measure), $P$-value } \\
\hline Unradiated-Control & & & 0.157 & $<0.0001^{*}$ & $<0.0001^{*}$ & $0.001^{*}$ & $<0.0001^{*}$ & 1.000 & $<0.0001^{*}$ \\
\hline Unradiated-Scramble & & & & $<0.0001^{*}$ & $<0.0001^{*}$ & 1.000 & $0.035^{\star}$ & 0.191 & $<0.0001^{\star}$ \\
\hline Unradiated-Mimics & & & & & $<0.0001^{*}$ & $<0.0001^{\star}$ & $<0.0001^{\star}$ & $<0.0001^{\star}$ & $<0.0001^{*}$ \\
\hline Unradiated-Inhibitor & & & & & & $<0.0001^{*}$ & $0.014^{\star}$ & $<0.0001^{\star}$ & 1.000 \\
\hline Radiated-Control & & & & & & & 1.000 & $0.001^{\star}$ & $<0.0001^{\star}$ \\
\hline Radiated-Scramble & & & & & & & & $<0.0001^{*}$ & $0.005^{\star}$ \\
\hline Radiated-Mimics & & & & & & & & & $<0.0001^{\star}$ \\
\hline
\end{tabular}

$I R$, ionizing radiation; Pre-treat, Pre-treatment.

${ }^{*}$ Indicates statistical significance, and relevant $P$ values are emphasized in bold. 
A
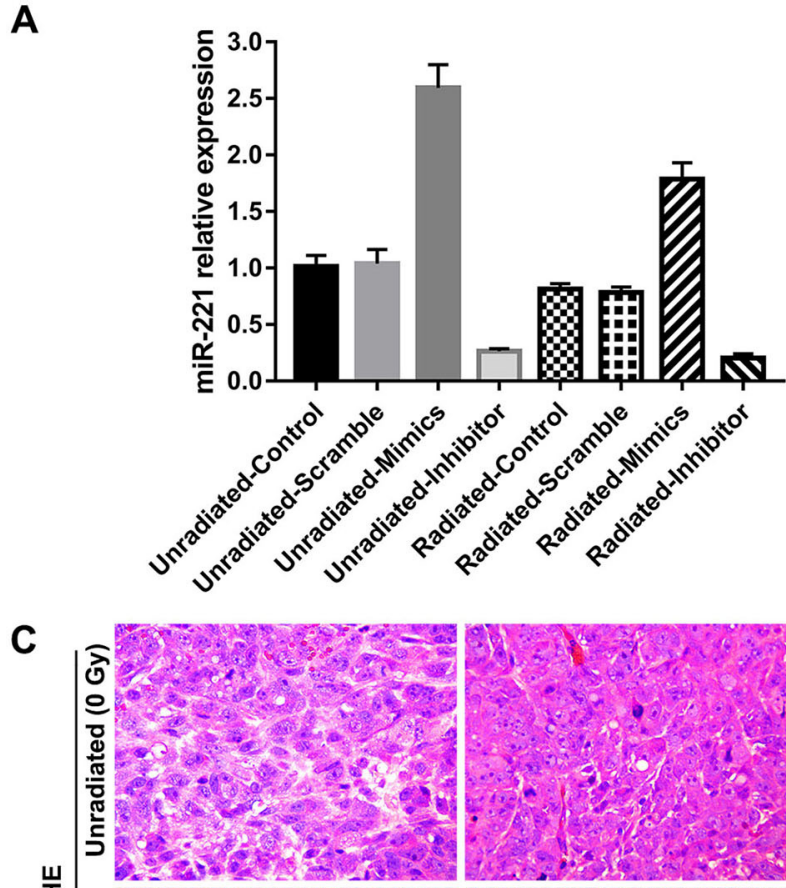

또
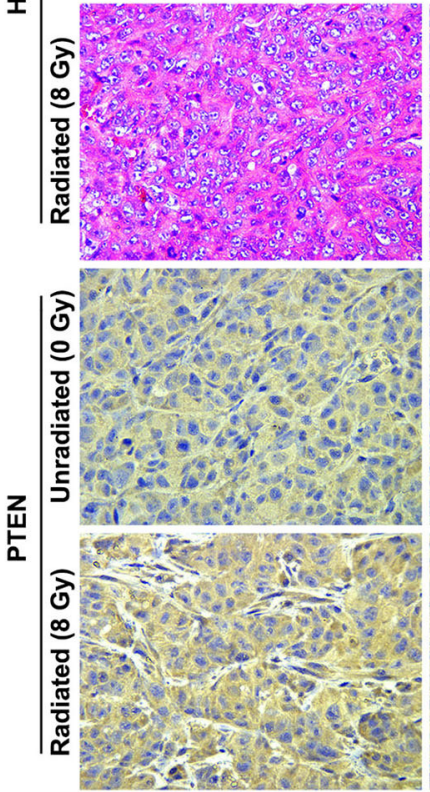

Control
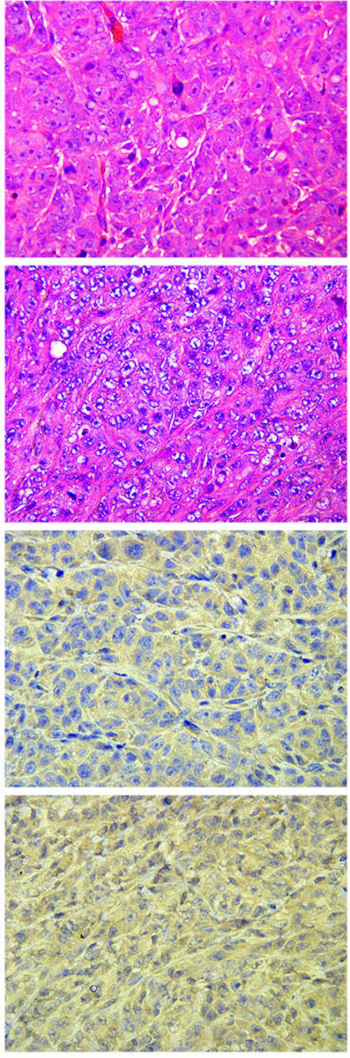

Scramble
B

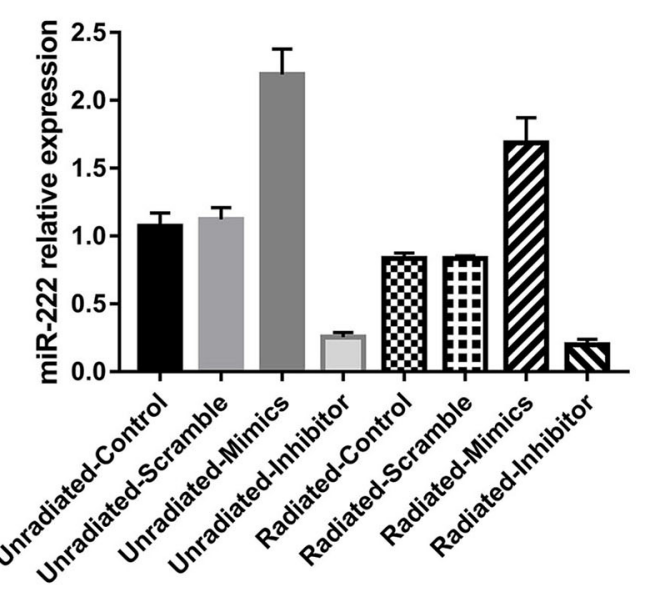

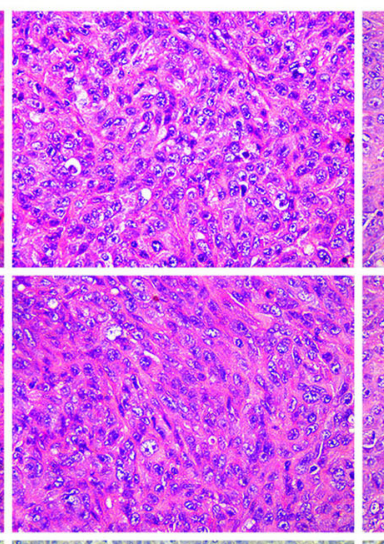
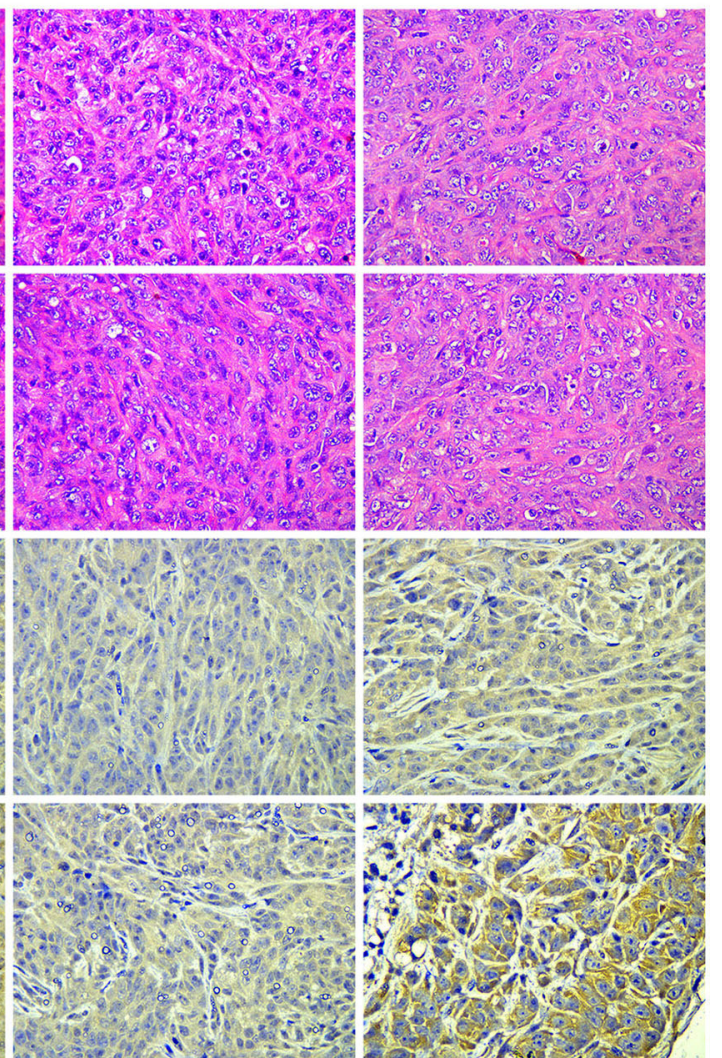

miR-221/222-mimics

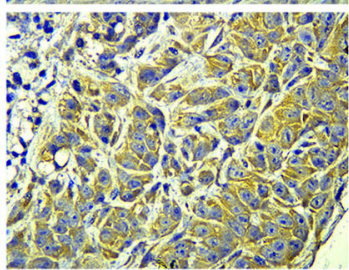

miR-221/222-inhibitor

FIGURE 4 | Downregulation of miR-221/222 expression and ionizing radiation promote the expression of phosphatase and tensin homolog (PTEN) in vivo. (A,B) Show the relative expressions of miR-221 and miR-222 in subcutaneous tumors of different subgroups, respectively. (C) Exhibits immunohistochemical staining for PTEN (bottom, 400x) and their corresponding H\&E staining (top, 400x) of tissue sections from each subgroup.

\section{Dose Rate of Irradiation Affects Cell Cycle Distribution of IOMM-Lee}

In previous studies of IOMM-Lee cells, (1) Gogineni et al. indicated that radiation treatment (7Gy) induced G2/M cell cycle arrest and a resultant decrease in the G0/G1 or S phase when evaluated against the unirradiated cells, as well as an insignificant cell-death-promoting effect (77). (2) However, by comparing the 5-Gy irradiated cells with unirradiated cells, Winson et al. exhibited a cell cycle distribution consist of an increased G0/G1, a decreased S, and an increased G2/M population, accompanied by an increment in apoptosis rate (78). The present results of radiation-induced G0/G1 cell cycle arrest and apoptosis-promoting effect are consistent with Winson's research while opposite to Gogineni's study (Tables 1-4 and 
Figures 1D-G). To determine the underlying causes of these opposites, we compared the data and discovered that the main difference is the dose rate, which was 0.71 and $3.2 \mathrm{~Gy} / \mathrm{min}$ in the Gogineni's study (77) and the present study, respectively, while Winson et al. did not provide theirs (78).

According to Hall's revised and updated illustration of the dose-rate effect (79), the dose-response curve becomes progressively shallower as the dose rate reduces, indicating an increment in sublethal damage repair. Cells rest on their cell cycle phase without progression. However, a further reduction in dose rate in a limited range allows cells to progress through the cycle and accumulate in G2, resulting in the inverse dose-rate effect. The critical dose rate of IOMM-Lee initiating this effect has not been determined. With a higher dose rate in the present study, the capability of cells to repair sublethal damage was restrained, which further leads to an increase in apoptotic rate with a fixed cell cycle distribution. The dose rate used by Gogineni et al. is lower, which might have triggered the inverse dose-rate effect. This dose rate might not significantly increase cell death but have gradually accumulated cells to rest on G2 phase, and these may explain their cell cycle and apoptosis results.

In Kurpinski's research of differential effects of X-rays on human mesenchymal stem cells (80), it is proved that X-ray at a high dose rate $(1 \mathrm{~Gy} / \mathrm{min})$ induces a significant increase in population of G0/G1 phase, a decrease in $\mathrm{S}$ phase, and no significant changes in $\mathrm{G} 2 / \mathrm{M}$ phase in comparison with a low dose rate counterpart $(0.1 \mathrm{~Gy} / \mathrm{min})$. We observed that the sub-G0/G1 population, which is referred to as an indicator of cell death, increased following a high dose rate radiation in IOMM-Lee cell (Tables 1, 2, 4 and Figures 1F,G). Combine with the dose-rate effect, these indicate that, within certain range, a higher doserate radiation treatment induces G0/G1 arrest and a relevant increased sub-G0/G1 population.

\section{LIMITATIONS}

It is noteworthy that the present research is based only on one single meningioma cell line IOMM-Lee, which may not comprehensively reflect other cell lines. Acquisition of other meningioma cell lines is beyond our ability, and the corresponding assays should be performed for comprehensive evaluation.

\section{CONCLUSION}

Radiation inhibits proliferation and promotes apoptosis and invasiveness in IOMM-Lee cells. Downregulating $m i R-221 / 222$ expression can reverse this radiation-induced cell invasiveness while enhancing the apoptosis-promoting and proliferationinhibiting effects of radiation and promoting cell radiosensitivity. Meanwhile, the dose rate of irradiation was also revealed to

\section{REFERENCES}

1. WHO classification of tumours of the central nervous system. Acta Neuropathol. (2007) 114:97-109. doi: 10.1007/s00401-007-0243-4 affect cell cycle distribution and cell apoptosis of IOMMLee. A high dose-rate irradiation induces G0/G1 cell cycle arrest and apoptosis-promoting effect. These findings suggest that the downregulation of $m i R-221 / 222$ is a promising method of improving radiotherapeutic efficacy and preventing postradiotherapeutic tumor recurrence. Future investigations of meningioma cells may focus on the interaction mechanisms between $m i R-221 / 222$ and IR-induced EMT and EMT-TFs, which may improve the understanding of radiotherapeutic toxicities and achieve more effective toxicity avoidance.

\section{DATA AVAILABILITY STATEMENT}

The datasets generated for this study can be found in the article/supplementary material.

\section{ETHICS STATEMENT}

The animal study was reviewed and approved by Animal Welfare Ethics Committee of Beijing Neurosurgical Institute (202001014).

\section{AUTHOR CONTRIBUTIONS}

QZ and L-RS: experimental implementation and acquisition of data. QZ, L-RS, X-LH, LW, G-BZ, S-YH, H-WJ, and C-LK: analysis and interpretation of data. QZ: drafting the article. J-TZ and G-JJ: approved the final version of the manuscript on behalf of all authors. J-TZ, G-JJ, WJ, ZW, LW, and B-NX: administrative, technical, and material support. All authors: conception and experimental design, critically revising the article, reviewed submitted version of manuscript, and study supervision.

\section{FUNDING}

This work was supported by the National Natural Science Foundation of China (Grant Number 81472370 to J-TZ) and the Beijing Natural Science Foundation (General Program) (Grant Number 7152050 to GJ, Grant Numbers J180005 and 7192056 to $\mathrm{ZW}$ ).

\section{ACKNOWLEDGMENTS}

The authors are grateful to the senior statisticians, Dr. Dan Xiao (Department of Epidemiology, China National Clinical Research Center for Neurological Disease, Beijing) and Dr. Wei Feng (Department of Epidemiology and Health Statistics, School of Public Health, Capital Medical University, Beijing) for their contributions to the supervision and guidance of the statistical analysis.

2. Kaur G, Sayegh ET, Larson A, Bloch O, Madden M, Sun MZ, et al. Adjuvant radiotherapy for atypical and malignant meningiomas: a systematic review. Neuro Oncol. (2014) 16:628-36. doi: 10.1093/neuonc/ nou025 
3. Aizer AA, Arvold ND, Catalano P, Claus EB, Golby AJ, Johnson MD, et al. Adjuvant radiation therapy, local recurrence, and the need for salvage therapy in atypical meningioma. Neuro Oncol. (2014) 16:154753. doi: 10.1093/neuonc/nou098

4. Endo T, Narisawa A, Ali HS, Murakami K, Watanabe T, Watanabe M, et al. A study of prognostic factors in 45 cases of atypical meningioma. Acta Neurochir. (2016) 158:1661-7. doi: 10.1007/s00701-016-2900-7

5. Hardesty DA, Wolf AB, Brachman DG, McBride HL, Youssef E, Nakaji P, et al. The impact of adjuvant stereotactic radiosurgery on atypical meningioma recurrence following aggressive microsurgical resection. J Neurosurg. (2013) 119:475-81. doi: 10.3171/2012.12.JNS12414

6. Hasan S, Young M, Albert T, Shah AH, Okoye C, Bregy A, et al. The role of adjuvant radiotherapy after gross total resection of atypical meningiomas. World Neurosurg. (2015) 83:808-15. doi: 10.1016/j.wneu.2014.12.037

7. Jenkinson MD, Waqar M, Farah JO, Farrell M, Barbagallo GM, McManus R, et al. Early adjuvant radiotherapy in the treatment of atypical meningioma. $J$ Clin Neurosci. (2016) 28:87-92. doi: 10.1016/j.jocn.2015.09.021

8. Wang YC, Chuang CC, Wei KC, Hsu YH, Hsu PW, Lee ST, et al. Skull base atypical meningioma: long term surgical outcome and prognostic factors. Clin Neurol Neurosurg. (2015) 128:112-6. doi: 10.1016/j.clineuro.2014.11.009

9. Coke CC, Corn BW, Werner-Wasik M, Xie Y, Curran WJ. Atypical and malignant meningiomas: an outcome report of seventeen cases. J Neurooncol. (1998) 39:65-70. doi: 10.1023/a:1005981731739

10. Goldsmith BJ, Wara WM, Wilson CB, Larson DA. Postoperative irradiation for subtotally resected meningiomas. A retrospective analysis of 140 patients treated from 1967 to 1990. J Neurosurg. (1994) 80:195-201. doi: 10.3171/jns.1994.80.2.0195

11. Hug EB, Devries A, Thornton AF, Munzenride JE, Pardo FS, Hedley-Whyte ET, et al. Management of atypical and malignant meningiomas: role of high-dose, 3D-conformal radiation therapy. J Neurooncol. (2000) 48:15160. doi: 10.1023/a:1006434124794

12. Milosevic MF, Frost PJ, Laperriere NJ, Wong CS, Simpson WJ. Radiotherapy for atypical or malignant intracranial meningioma. Int J Radiat Oncol Biol Phys. (1996) 34:817-22.

13. Weber DC, Ares C, Villa S, Peerdeman SM, Renard L, Baumert $\mathrm{BG}$, et al. Adjuvant postoperative high-dose radiotherapy for atypical and malignant meningioma: a phase-II parallel non-randomized and observation study (EORTC 22042-26042). Radiother Oncol. (2018) 128:2605. doi: 10.1016/j.radonc.2018.06.018

14. Aghi MK, Carter BS, Cosgrove GR, Ojemann RG, Amin-Hanjani S, Martuza $\mathrm{RL}$, et al. Long-term recurrence rates of atypical meningiomas after gross total resection with or without postoperative adjuvant radiation. Neurosurgery. (2009) 64:56-60; discussion 60. doi: 10.1227/01.NEU.0000330399.55586.63

15. Bartel DP. MicroRNAs: genomics, biogenesis, mechanism, and function. Cell. (2004) 116:281-97. doi: 10.1016/s0092-8674(04)00045-5

16. Davis BN, Hata A. Regulation of MicroRNA Biogenesis: A miRiad of mechanisms. Cell Commun Signal. (2009) 7:18. doi: 10.1186/1478-811X-7-18

17. Anindo MI, Yaqinuddin A. Insights into the potential use of microRNAs as biomarker in cancer. Int J Surg. (2012) 10:443-9. doi: 10.1016/j.ijsu.2012.08.006

18. El-Gewely MR, Andreassen M, Walquist M, Ursvik A, Knutsen E, Nystad $\mathrm{M}$, et al. Differentially expressed MicroRNAs in meningiomas grades I and II suggest shared biomarkers with malignant tumors. Cancers. (2016) 8:31. doi: 10.3390/cancers8030031

19. Kliese N, Gobrecht P, Pachow D, Andrae N, Wilisch-Neumann A, Kirches E, et al. miRNA-145 is downregulated in atypical and anaplastic meningiomas and negatively regulates motility and proliferation of meningioma cells. Oncogene. (2013) 32:4712-20. doi: 10.1038/onc.2012.468

20. Saydam O, Shen Y, Würdinger T, Senol O, Boke E, James MF, et al. Downregulated microRNA-200a in meningiomas promotes tumor growth by reducing E-cadherin and activating the Wnt/beta-catenin signaling pathway. Mol Cell Biol. (2009) 29:5923-40. doi: 10.1128/MCB.00332-09

21. Shi L, Jiang D, Sun G, Wan Y, Zhang S, Zeng Y, et al. miR-335 promotes cell proliferation by directly targeting Rb1 in meningiomas. J Neurooncol. (2012) 110:155-62. doi: 10.1007/s11060-012-0951-z

22. Dalan AB, Gulluoglu S, Tuysuz EC, Kuskucu A, Yaltirik CK, Ozturk O, et al. Simultaneous analysis of miRNA-mRNA in human meningiomas by integrating transcriptome: a relationship between PTX3 and miR-29c. BMC Cancer. (2017) 17:207. doi: 10.1186/s12885-017-3198-4
23. Li P, Gao Y, Li F, Pan Q, Liu Z, Lu X, et al. MicroRNA-18a regulates invasive meningiomas via hypoxia-inducible factor-1 $\alpha$. Exp Ther Med. (2015) 10:1165-70. doi: 10.3892/etm.2015.2630

24. Senol O, Schaaij-Visser TB, Erkan EP, Dorfer C, Lewandrowski G, Pham $\mathrm{TV}$, et al. miR-200a-mediated suppression of non-muscle heavy chain IIb inhibits meningioma cell migration and tumor growth in vivo. Oncogene. (2015) 34:1790-8. doi: 10.1038/onc.2014.120

25. Wang M, Deng X, Ying Q, Jin T, Li M, Liang C. MicroRNA-224 targets ERG2 and contributes to malignant progressions of meningioma. Biochem Biophys Res Commun. (2015) 460:354-61. doi: 10.1016/j.bbrc.2015.03.038

26. Zhi F, Shao N, Li B, Xue L, Deng D, Xu Y, et al. A serum 6-miRNA panel as a novel non-invasive biomarker for meningioma. Sci Rep. (2016) 6:32067. doi: 10.1038/srep32067

27. Zhi F, Zhou G, Wang S, Shi Y, Peng Y, Shao N, et al. A microRNA expression signature predicts meningioma recurrence. Int J Cancer. (2013) 132:12836. doi: $10.1002 /$ ijc. 27658

28. Galani V, Alexiou GA, Miliaras G, Dimitriadis E, Triantafyllou E, Galani A, et al. Expression of stem cell marker Nestin and MicroRNA-21 in Meningiomas. Turk Neurosurg. (2015) 25:574-7. doi: 10.5137/1019-5149.JTN.10800-14.2

29. Katar S, Baran O, Evran S, Cevik S, Akkaya E, Baran G, et al. Expression of miRNA-21, miRNA-107, miRNA-137 and miRNA-29b in meningioma. Clin Neurol Neurosurg. (2017) 156:66-70. doi: 10.1016/j.clineuro.2017.03.016

30. Zhang C, Kang C, You Y, Pu P, Yang W, Zhao P, et al. Co-suppression of miR221/222 cluster suppresses human glioma cell growth by targeting p27kip1 in vitro and in vivo. Int J Oncol. (2009) 34:1653-60. doi: 10.3892/ijo_00 000296

31. Chun-Zhi Z, Lei H, An-Ling Z, Yan-Chao F, Xiao Y, Guang-Xiu W, et al. MicroRNA-221 and microRNA-222 regulate gastric carcinoma cell proliferation and radioresistance by targeting PTEN. BMC Cancer. (2010) 10:367. doi: 10.1186/1471-2407-10-367

32. Khoshinani HM, Afshar S, Pashaki AS, Mahdavinezhad A, Nikzad S, Najafi $\mathrm{R}$, et al. Involvement of miR-155/FOXO3a and miR-222/PTEN in acquired radioresistance of colorectal cancer cell line. Jpn J Radiol. (2017) 35:66472. doi: 10.1007/s11604-017-0679-y

33. Xue Q, Sun K, Deng HJ, Lei ST, Dong JQ, Li GX. Anti-miRNA-221 sensitizes human colorectal carcinoma cells to radiation by upregulating PTEN. World J Gastroenterol. (2013) 19:9307-17. doi: 10.3748/wjg.v19.i48.9307

34. Wu W, Chen X, Yu S, Wang R, Zhao R, Du C. microRNA-222 promotes tumor growth and confers radioresistance in nasopharyngeal carcinoma by targeting PTEN. Mol Med Rep. (2018) 17:1305-10. doi: 10.3892/mmr.2017.7931

35. De Bacco F, Luraghi P, Medico E, Reato G, Girolami F, Perera T, et al. Induction of MET by ionizing radiation and its role in radioresistance and invasive growth of cancer. J Natl Cancer Inst. (2011) 103:64561. doi: 10.1093/jnci/djr093

36. Kawamoto A, Yokoe T, Tanaka K, Saigusa S, Toiyama Y, Yasuda H, et al. Radiation induces epithelial-mesenchymal transition in colorectal cancer cells. Oncol Rep. (2012) 27:51-7. doi: 10.3892/or.2011.1485

37. Moncharmont C, Levy A, Guy JB, Falk AT, Guilbert M, Trone JC, et al. Radiation-enhanced cell migration/invasion process: a review. Crit Rev Oncol Hematol. (2014) 92:133-42. doi: 10.1016/j.critrevonc.2014.05.006

38. Park JK, Jang SJ, Kang SW, Park S, Hwang SG, Kim WJ, et al. Establishment of animal model for the analysis of cancer cell metastasis during radiotherapy. Radiat Oncol. (2012) 7:153. doi: 10.1186/1748-717X-7-153

39. Wild-Bode C, Weller M, Rimner A, Dichgans J, Wick W. Sublethal irradiation promotes migration and invasiveness of glioma cells: implications for radiotherapy of human glioblastoma. Cancer Res. (2001) 61:2744-50.

40. Zhang X, Li X, Zhang N, Yang Q, Moran MS. Low doses ionizing radiation enhances the invasiveness of breast cancer cells by inducing epithelialmesenchymal transition. Biochem Biophys Res Commun. (2011) 412:18892. doi: 10.1016/j.bbrc.2011.07.074

41. Puisieux A, Brabletz T, Caramel J. Oncogenic roles of EMT-inducing transcription factors. Nat Cell Biol. (2014) 16:488-94. doi: 10.1038/ncb2976

42. Lee SY, Jeong EK, Ju MK, Jeon HM, Kim MY, Kim CH, et al. Induction of metastasis, cancer stem cell phenotype, and oncogenic metabolism in cancer cells by ionizing radiation. Mol Cancer. (2017) 16:10. doi: 10.1186/s12943-016-0577-4

43. Peinado H, Olmeda D, Cano A. Snail, Zeb and bHLH factors in tumour progression: an alliance against the epithelial phenotype. Nat Rev Cancer. (2007) 7:415-28. doi: 10.1038/nrc2131 
44. Wang Y, Shi J, Chai K, Ying X, Zhou BP. The Role of Snail in EMT and tumorigenesis. Curr Cancer Drug Targets. (2013) 13:96372. doi: $10.2174 / 15680096113136660102$

45. Ansieau S, Collin G, Hill L. EMT or EMT-promoting transcription factors, where to focus the light. Front Oncol. (2014) 4:353. doi: 10.3389/fonc.2014.00353

46. Zhang Q, Jia GJ, Zhang GB, Wang L, Wu Z, Jia W, et al. A logistic regression model for detecting the presence of malignant progression in atypical meningiomas. World Neurosurg. (2019) 126:e392-401. doi: 10.1016/j.wneu.2019.02.062

47. Söhl G, Maxeiner S, Willecke K. Expression and functions of neuronal gap junctions. Nat Rev Neurosci. (2005) 6:191-200. doi: 10.1038/nrn1627

48. Cina C, Bechberger JF, Ozog MA, Naus CC. Expression of connexins in embryonic mouse neocortical development. J Comp Neurol. (2007) 504:298313. doi: 10.1002/cne.21426

49. Aasen T, Mesnil M, Naus CC, Lampe PD, Laird DW. Gap junctions and cancer: communicating for 50 years. Nat Rev Cancer. (2016) 16:77588. doi: $10.1038 / \mathrm{nrc} .2016 .105$

50. Kar R, Batra N, Riquelme MA, Jiang JX. Biological role of connexin intercellular channels and hemichannels. Arch Biochem Biophys. (2012) 524:215. doi: 10.1016/j.abb.2012.03.008

51. Al-Mefty O, Kadri PA, Pravdenkova S, Sawyer JR, Stangeby C, Husain M. Malignant progression in meningioma: documentation of a series and analysis of cytogenetic findings. J Neurosurg. (2004) 101:210-8. doi: 10.3171/jns.2004.101.2.0210

52. Arishima H, Sato K, Kubota T. Immunohistochemical and ultrastructural study of gap junction proteins connexin 26 and 43 in human arachnoid villi and meningeal tumors. J Neuropathol Exp Neurol. (2002) 61:104855. doi: 10.1093/jnen/61.12.1048

53. Shaw RJ, Cantley LC. Ras, PI(3)K and mTOR signalling controls tumour cell growth. Nature. (2006) 441:424-30. doi: 10.1038/nature04869

54. Maehama T. PTEN: its deregulation and tumorigenesis. Biol Pharm Bull. (2007) 30:1624-7. doi: 10.1248/bpb.30.1624

55. Mulholland DJ, Kobayashi N, Ruscetti M, Zhi A, Tran LM, Huang J, et al. Pten loss and RAS/MAPK activation cooperate to promote EMT and metastasis initiated from prostate cancer stem/progenitor cells. Cancer Res. (2012) 72:1878-89. doi: 10.1158/0008-5472.CAN-11-3132

56. Lee JY, Nakada D, Yilmaz OH, Tothova Z, Joseph NM, Lim MS, et al. mTOR activation induces tumor suppressors that inhibit leukemogenesis and deplete hematopoietic stem cells after Pten deletion. Cell Stem Cell. (2010) 7:593-605. doi: 10.1016/j.stem.2010.09.015

57. Santivasi WL, Xia F. Ionizing radiation-induced DNA damage, response, and repair. Antioxid Redox Signal. (2014) 21:251-9. doi: 10.1089/ars.2013.5668

58. Ou YH, Chung PH, Sun TP, Shieh SY. p53 C-terminal phosphorylation by $\mathrm{CHK} 1$ and $\mathrm{CHK} 2$ participates in the regulation of DNAdamage-induced C-terminal acetylation. Mol Biol Cell. (2005) 16:1684-95. doi: 10.1091/mbc.e04-08-0689

59. Chehab NH, Malikzay A, Appel M, Halazonetis TD. Chk2/hCds1 functions as a DNA damage checkpoint in $\mathrm{G}(1)$ by stabilizing p53. Genes Dev. (2000) 14:278-88.

60. Shieh SY, Ahn J, Tamai K, Taya Y, Prives C. The human homologs of checkpoint kinases Chk1 and Cds1 (Chk2) phosphorylate p53 at multiple DNA damage-inducible sites. Genes Dev. (2000) 14:289-300.

61. Friedberg EC. DNA damage and repair. Nature. (2003) 421:43640. doi: $10.1038 /$ nature 01408

62. Levine AJ. p53, the cellular gatekeeper for growth and division. Cell. (1997) 88:323-31. doi: 10.1016/s0092-8674(00)81871-1

63. Ko LJ, Prives C. p53: puzzle and paradigm. Genes Dev. (1996) 10:105472. doi: $10.1101 /$ gad.10.9.1054

64. Gudkov AV, Komarova EA. The role of p53 in determining sensitivity to radiotherapy. Nat Rev Cancer. (2003) 3:117-29. doi: 10.1038/nrc992

65. Surova O, Zhivotovsky B. Various modes of cell death induced by DNA damage. Oncogene. (2013) 32:3789-97. doi: 10.1038/onc.2012.556

66. Freeman DJ, Li AG, Wei G, Li HH, Kertesz N, Lesche R, et al. PTEN tumor suppressor regulates p53 protein levels and activity through phosphatasedependent and -independent mechanisms. Cancer Cell. (2003) 3:11730. doi: 10.1016/s1535-6108(03)00021-7
67. Jung IL, Kang HJ, Kim KC, Kim IG. PTEN/pAkt/p53 signaling pathway correlates with the radioresponse of non-small cell lung cancer. Int J Mol Med. (2010) 25:517-23. doi: 10.3892/ijmm_00000372

68. Rosser CJ, Tanaka M, Pisters LL, Tanaka N, Levy LB, Hoover DC, et al. Adenoviral-mediated PTEN transgene expression sensitizes Bcl-2-expressing prostate cancer cells to radiation. Cancer Gene Ther. (2004) 11:2739. doi: $10.1038 /$ s..cgt.7700673

69. Qu C, Liang Z, Huang J, Zhao R, Su C, Wang S, et al. MiR-205 determines the radioresistance of human nasopharyngeal carcinoma by directly targeting PTEN. Cell Cycle. (2012) 11:785-96. doi: 10.4161/cc.11.4. 19228

70. Ma X, Zhou J, Liu J, Wu G, Yu Y, Zhu H, et al. LncRNA ANCR promotes proliferation and radiation resistance of nasopharyngeal carcinoma by inhibiting PTEN expression. Onco Targets Ther. (2018) 11:8399408. doi: $10.2147 /$ OTT.S182573

71. Zhang G, Wang W, Yao C, Zhang S, Liang L, Han M, et al. Radiationresistant cancer stem-like cell properties are regulated by PTEN through the activity of nuclear $\beta$-catenin in nasopharyngeal carcinoma. Oncotarget. (2017) 8:74661-72. doi: 10.18632/oncotarget.20339

72. Pappas G, Zumstein LA, Munshi A, Hobbs M, Meyn RE. Adenoviralmediated PTEN expression radiosensitizes non-small cell lung cancer cells by suppressing DNA repair capacity. Cancer Gene Ther. (2007) 14:5439. doi: $10.1038 /$ s..cgt.7701050

73. Zhang Y, Zheng L, Ding Y, Li Q, Wang R, Liu T, et al. MiR-20a Induces Cell Radioresistance by Activating the PTEN/PI3K/Akt Signaling Pathway in Hepatocellular Carcinoma. Int J Radiat Oncol Biol Phys. (2015) 92:113240. doi: 10.1016/j.ijrobp.2015.04.007

74. Jin $\mathrm{Y}, \mathrm{Xu} \mathrm{K}$, Chen $\mathrm{Q}$, Wang $\mathrm{B}$, Pan J, Huang S, et al. Simvastatin inhibits the development of radioresistant esophageal cancer cells by increasing the radiosensitivity and reversing EMT process via the PTENPI3K/AKT pathway. Exp Cell Res. (2018) 362:362-9. doi: 10.1016/j.yexcr.2017. 11.037

75. Liang YK, Lin HY, Dou XW, Chen M, Wei XL, Zhang YQ, et al. MiR-221/222 promote epithelial-mesenchymal transition by targeting Notch3 in breast cancer cell lines. NPJ Breast Cancer. (2018) 4:20. doi: 10.1038/s41523-018-0073-7

76. Garofalo M, Di LG, Romano G, Nuovo G, Suh SS, Ngankeu A, et al. miR-221\&222 regulate TRAIL resistance and enhance tumorigenicity through PTEN and TIMP3 downregulation. Cancer Cell. (2009) 16:498509. doi: 10.1016/j.ccr.2009.10.014

77. Gogineni VR, Nalla AK, Gupta R, Dinh DH, Klopfenstein JD, Rao JS. Chk2-mediated G2/M cell cycle arrest maintains radiation resistance in malignant meningioma cells. Cancer Lett. (2011) 313:64-75. doi: 10.1016/j.canlet.2011.08.022

78. Ho WS, Sizdahkhani S, Hao S, Song H, Seldomridge A, Tandle A, et al. LB100, a novel Protein Phosphatase 2A (PP2A) inhibitor, sensitizes malignant meningioma cells to the therapeutic effects of radiation. Cancer Lett. (2018) 415:217-26. doi: 10.1016/j.canlet.2017.11.035

79. Hall EJ, Brenner DJ. The dose-rate effect revisited: radiobiological considerations of importance in radiotherapy. Int J Radiat Oncol Biol Phys. (1991) 21:1403-14. doi: 10.1016/0360-3016(91)90314-t

80. Kurpinski K, Jang DJ, Bhattacharya S, Rydberg B, Chu J, So J, et al. Differential effects of $\mathrm{x}$-rays and high-energy $56 \mathrm{Fe}$ ions on human mesenchymal stem cells. Int J Radiat Oncol Biol Phys. (2009) 73:86977. doi: $10.1016 /$ j.ijrobp.2008.10.002

Conflict of Interest: The authors declare that the research was conducted in the absence of any commercial or financial relationships that could be construed as a potential conflict of interest.

Copyright $\odot 2020$ Zhang, Song, Huo, Wang, Zhang, Hao, Jia, Kong, Jia, Wu, Xu, Jia and Zhang. This is an open-access article distributed under the terms of the Creative Commons Attribution License (CC BY). The use, distribution or reproduction in other forums is permitted, provided the original author(s) and the copyright owner(s) are credited and that the original publication in this journal is cited, in accordance with accepted academic practice. No use, distribution or reproduction is permitted which does not comply with these terms. 